\title{
Lanthanum Ferrites-Based Exsolved Perovskites as Fuel-Flexible Anode for Solid Oxide Fuel Cells
}

\author{
Massimiliano Lo Faro * $\mathbb{D}$, Sabrina Campagna Zignani and Antonino Salvatore Aricò \\ CNR-ITAE, Istituto di Tecnologie Avanzate per l'Energia "Nicola Giordano", Via Salita S. Lucia sopra Contesse 5, \\ 98126 Messina, Italy; zignani@itae.cnr.it (S.C.Z.); arico@itae.cnr.it (A.S.A.) \\ * Correspondence: lofaro@itae.cnr.it; Tel.: +39-090624243
}

Received: 11 June 2020; Accepted: 16 July 2020; Published: 20 July 2020

\begin{abstract}
Exsolved perovskites can be obtained from lanthanum ferrites, such as $\mathrm{La}_{0.6} \mathrm{Sr}_{0.4} \mathrm{Fe}_{0.8} \mathrm{Co}_{0.2} \mathrm{O}_{3}$, as result of Ni doping and thermal treatments. Ni can be simply added to the perovskite by an incipient wetness method. Thermal treatments that favor the exsolution process include calcination in air (e.g., $500{ }^{\circ} \mathrm{C}$ ) and subsequent reduction in diluted $\mathrm{H}_{2}$ at $800{ }^{\circ} \mathrm{C}$. These processes allow producing a two-phase material consisting of a Ruddlesden-Popper-type structure and a solid oxide solution e.g., $\alpha-\mathrm{Fe}_{100-\mathrm{y}-\mathrm{z}} \mathrm{Co}_{y} \mathrm{Ni}_{\mathrm{z}} \mathrm{O}_{\mathrm{x}}$ oxide. The formed electrocatalyst shows sufficient electronic conductivity under reducing environment at the Solid Oxide Fuel Cell (SOFC) anode. Outstanding catalytic properties are observed for the direct oxidation of dry fuels in SOFCs, including $\mathrm{H}_{2}$, methane, syngas, methanol, glycerol, and propane. This anode electrocatalyst can be combined with a full density electrolyte based on Gadolinia-doped ceria or with $\mathrm{La}_{0.8} \mathrm{Sr}_{0.2} \mathrm{Ga}_{0.8} \mathrm{Mg}_{0.2} \mathrm{O}_{3}$ (LSGM) or $\mathrm{BaCe}_{0.9} \mathrm{Y}_{0.1} \mathrm{O}_{3-\delta}$ (BYCO) to form a complete perovskite structure-based cell. Moreover, the exsolved perovskite can be used as a coating layer or catalytic pre-layer of a conventional Ni-YSZ anode. Beside the excellent catalytic activity, this material also shows proper durability and tolerance to sulfur poisoning. Research challenges and future directions are discussed. A new approach combining an exsolved perovskite and an $\mathrm{NiCu}$ alloy to further enhance the fuel flexibility of the composite catalyst is also considered. In this review, the preparation methods, physicochemical characteristics, and surface properties of exsoluted fine nanoparticles encapsulated on the metal-depleted perovskite, electrochemical properties for the direct oxidation of dry fuels, and related electrooxidation mechanisms are examined and discussed.
\end{abstract}

Keywords: perovskite; electrooxidation; fuel flexibility; renewables; anode

\section{Introduction}

Achieving fuel flexibility in fuel cells has been a focus of high-temperature fuel cells since their discovery [1,2]. As Solid Oxide Fuel Cells (SOFCs) operate at temperatures close or higher than 800 ${ }^{\circ} \mathrm{C}$, their thermodynamics allow the direct use of dry organic fuels or organic fuels in combination with water [3]. However, practical operation requires a pre-treatment of organic fuels to convert hydrocarbon and remove sulfur traces [4]. In parallel, the discovery of new materials and novel cell designs has allowed reducing the operating temperature to $600-800{ }^{\circ} \mathrm{C}[5,6]$. Several studies have been concerned with the development of novel materials $[7,8]$ and in particular novel anodes for advanced SOFCs operating in fuel-flexible mode [9-13].

Fuel flexibility is treated in this review article in relation to a specific category of electrocatalysts.

Although novel SOFCs designs and several new materials have been investigated, $\mathrm{Ni}$ in combination with Yttria-stabilized Zirconia (YSZ) still represents today the selected approach for the anode [14]. This is because the Ni-YSZ cermet provides a proper trade-off in terms of electrochemical, thermal, and mechanical properties [15-22]. In particular, the mechanical and thermal properties of Ni-YSZ are rather flexible and adequate to the production chain of anode-supported SOFC cells [23-25]. 
However, the degradation of Ni-YSZ anodes during SOFC operation is frequently reported. This occurs due to the coarsening of Ni particles [16] and to the carbon deposition [20]. Moreover, another drawback is related to the risk of $\mathrm{Ni}$ poisoning due to sulfur contaminants and pore blocking associated with the deposition of carbon tar [26-28]. Accordingly, large SOFC systems include a fuel pre-reformer and a desulfurizer [15,29-31]. An alternative strategy for SOFC systems' simplification, which has been quite recently adopted, consists of the use of a functional layer coated on the external side of Ni-YSZ anodes [32]. Due to the favorable electronic properties, $\mathrm{Ni}$ alloys in combination with doped ceria electrolyte have been widely investigated to replace bare $\mathrm{Ni}$ [33-35]. The specific advantage relies on a breaking effect of the crystallographic arrangement of $\mathrm{Ni}$ atoms, which is responsible for the cracking mechanism of hydrocarbons [36,37]. This effect has been achieved by the inclusion of a different transition metal, not adsorbing carbon, into the reticular scaffold of $\mathrm{Ni}$. The metals selected for this inclusion were somehow inert toward the cracking reaction (e.g., Cu) [33] or capable of modifying the surface electronic density and the lattice distances of the regular $\mathrm{Ni}-\mathrm{Ni}$ crystallographic network (e.g., Co) [34], or a combination of all these effects (e.g., Fe) [35]. Then, a further optimization has been achieved by adopting different synthesis methods with the aim of improving the homogeneity of the solid solution and consequently reducing the probability of $\mathrm{Ni}-\mathrm{Ni}$ bonds' occurrence on the surface [37].

Moreover, specific catalyst functionalization has been made by increasing its oxygen storage capability [38], e.g., by adding oxygen storage additives such as ceria. This is particularly desired to promote the oxidation of a fuel and to extend the "triple phase boundary" $[39,40]$. These are the sites where the electrochemical reactions take place. Thus, the alloy is generally mixed with doped ceria, which is a well-known oxygen storage material as a consequence of its peculiar redox properties [10]. Although this approach has been revealed as promising for the direct use of dry organic molecules in SOFCs [41,42], to date, there has been limited evidence about the resistance of these Ni alloy-ceria composite catalysts toward sulfur poisoning.

An approach combining both sulfur resistance and organic fuel oxidation capabilities consists of the use of exsolved perovskites at the anode [43]. $\mathrm{ABX}_{3}$ is the general chemical formula of these materials. A and B are the sites occupied by cations with different sizes (e.g., La and Sr for the A site and $\mathrm{Fe}$ and $\mathrm{Co}$ for the $\mathrm{B}$ site) and different valence states. $\mathrm{X}$ is the site for the oxygen anions [44]. These materials may be tuned in both A and B sites by using different cations and doping in order to achieve the desired amount of holes and vacancies that are required for high ionic and electronic conductivity [45-47]. The idea of using perovskites at the anode is more recent. It raised from the large amount of evidence about their activity toward the cleavage of $\mathrm{C}-\mathrm{H}, \mathrm{C}-\mathrm{C}$, and $\mathrm{C}=\mathrm{C}$ bonds $[46,48,49]$ with a relatively good stability in the presence of sulfur-based products [50,51]. These systems are also characterized by mixed electronic and ionic conductivity [52], even if the electronic conductivity is not comparable to that of a metal also at the high operating temperatures of an SOFC. On the other hand, the perovskites may present the drawbacks of a limited structural stability under the reducing environment of an SOFC anode [53,54]. To address this issue, the modification of perovskites ex ante with the aim of functionalizing their surface and tailoring the activity for the anodic reactions, while stabilizing the structure and improving the electronic conductivity, has been carried out $[43,55]$. A further step forward in tailoring these perovskite materials for the use as an anode in SOFCs is relying on the addition of ceria to increase the oxygen storage capacity and the electronic/ionic percolation.

The authors of this mini-review have intensively worked on modified and exsolved perovskite for application as an anode in SOFCs for several years demonstrating an effective oxidation of various organic fuels directly fed to the cell [56-63]. The proper modification of commercial type ferrite-based perovskites, which are commonly used as an SOFC cathode, with small amounts of Ni has been demonstrated. The process has been enhanced by tailoring the thermal treatments to consolidate the modified perovskite structure. In this mini-review, we have summarized the properties of these novel anode materials, their performance in SOFCs, and the specific reaction mechanisms investigated through a combination of electrochemical experiments and the chromatographic analyses of effluents. 


\section{Surface Exsolution and Physicochemical Studies}

The exsolution of fine particles from the perovskite surface is an approach recently used for the functionalization of perovskite materials for anodic applications [64-66]. Two main approaches have been developed: (1) synthesis of a non-stoichiometric perovskite host [67] and (2) surface impregnation of a raw perovskite with a foreign transition element $[68,69]$. The final modification is thermal driven by a process under reducing condition at high temperature in order to achieve a proper thermodynamic stability for the fine exsolved nanoparticles embedded in the perovskite substrate. The latter remains deficient of cations in A and B sites. Both approaches have been addressed to promote a similar distribution of fine exsolved particles on the surface. It was reported that the first method should be preferred in case of high risks for their coarsening [70].

Many exsolved perovskites have been synthesized using these approaches for various applications and with the aim of functionalizing the surface of these materials. One of the most used applications has regarded their use as a novel anode for SOFCs. The subject of this mini-review is specifically addressing the modification of ferrite-based perovskites commonly used as cathodes in commercial-type SOFCs operating in the temperature range between 700 and $800{ }^{\circ} \mathrm{C}$. This type of perovskite generally has the formula $\mathrm{La}_{0.6} \mathrm{Sr}_{0.4} \mathrm{Fe}_{0.8} \mathrm{Co}_{0.2} \mathrm{O}_{3}$ (LSFC). The raw LSFC that we have largely used in our previous works had a surface of $5.20 \mathrm{~m}^{2} \mathrm{~g}^{-1}$ and was purchased from Praxair. By using a wet impregnation method, $20 \mathrm{~cm}^{3}$ of an aqueous solution containing $3 \mathrm{wt} \%$ of Ni as Ni nitrate (Sigma Aldrich) has been deposited drop-by-drop on the perovskite, and this was maintained under stirring condition at $80^{\circ} \mathrm{C}$. After drying at $150{ }^{\circ} \mathrm{C}$ for $8 \mathrm{~h}$, the powder has been treated at $500{ }^{\circ} \mathrm{C}$ in static air for $2 \mathrm{~h}$ and then reduced with $5 \%$ of $\mathrm{H}_{2}$ in $\mathrm{N}_{2}$ at $800{ }^{\circ} \mathrm{C}$ for $2 \mathrm{~h}$ and then re-calcined at $500{ }^{\circ} \mathrm{C}$ in static air for $2 \mathrm{~h}$ to stabilize the nanoparticles on the surface. The amount of $\mathrm{Ni}$ added to the perovskite was evaluated on the basis of a compromise between the need of avoiding large occurrence of metallic nickel on the surface with the consequent risk of carbon deposition during the cracking of organic fuels and to favor just a partial exsolution of $\mathrm{Fe}$ and $\mathrm{Co}$ from the perovskite. The subsequent step consisted in the grinding for $12 \mathrm{~h}$ of this powder together with gadolinia-doped ceria $\left(\mathrm{Gd}_{0.1} \mathrm{Ce}_{0.9} \mathrm{O}_{2}-\mathrm{GDC}\right.$, Praxair) with a surface area of $38.92 \mathrm{~m}^{2} \mathrm{~g}^{-1}$. The doping of perovskite with $\mathrm{Ni}$ and its subsequent thermal treatments caused a modification of the initial perovskite phase originated from the depletion of $\mathrm{Co}$ and Fe with the consequent formation of a new phase named as $n=1$ Ruddlesden-Popper $\left(A_{n+1} B_{n} O_{3 n+1}\right)$ structure [71,72]. Figure 1 shows the XRD spectra of the raw and modified perovskites. Fe and Co are located in the blue octahedrals, and the green spheres are related to the sites of $\mathrm{La}$ and $\mathrm{Sr}$, whereas the red spheres are the sites for oxygen ions. As a consequence of perovskite distortion, the ratio $\mathrm{La} / \mathrm{Sr}$ $(0.6 / 0.4)$ remained the same during the perovskite modification, whereas the Fe/Co ratio was altered as a consequence of the $\mathrm{Co}$ and Fe depletion from the bulk and their migration to the perovskite surface (the $\mathrm{Fe} / \mathrm{Co}$ ratio was originally 4 in the raw perovskite). The overall amount of Ruddlesden-Popper $n=1$ phase was approximately $60 \mathrm{wt} \%$ as determined through a least-square fitting profile quantitative analysis procedure. As evidenced by previous High Resolution-Transmission Electronic Microscopy (HR-TEM) and Energy-Dispersive X-ray (EDX) analyses [62], the exsolution process involves the occurrence of a secondary phase related to fine exsolved particles encapsulated on the surface. These are composed of a tri-metallic alloy (e.g., Ni-Fe-Co, about $25 \mathrm{~nm}$ ) in the core and a shell of mixed oxides (e.g., $\alpha-\mathrm{Fe}_{100-y-z} \mathrm{Co}_{y} \mathrm{Ni}_{z} \mathrm{O}_{x}$, about $2 \mathrm{~nm}$ ). Smith et al. $[73,74]$ have reported that this mixed oxide has shown reversible electrochemical behavior starting from low temperatures. Accordingly, it has been also suggested as a substitution of noble metals for the water electrolysis in zero-gap cells $[73,74]$. 


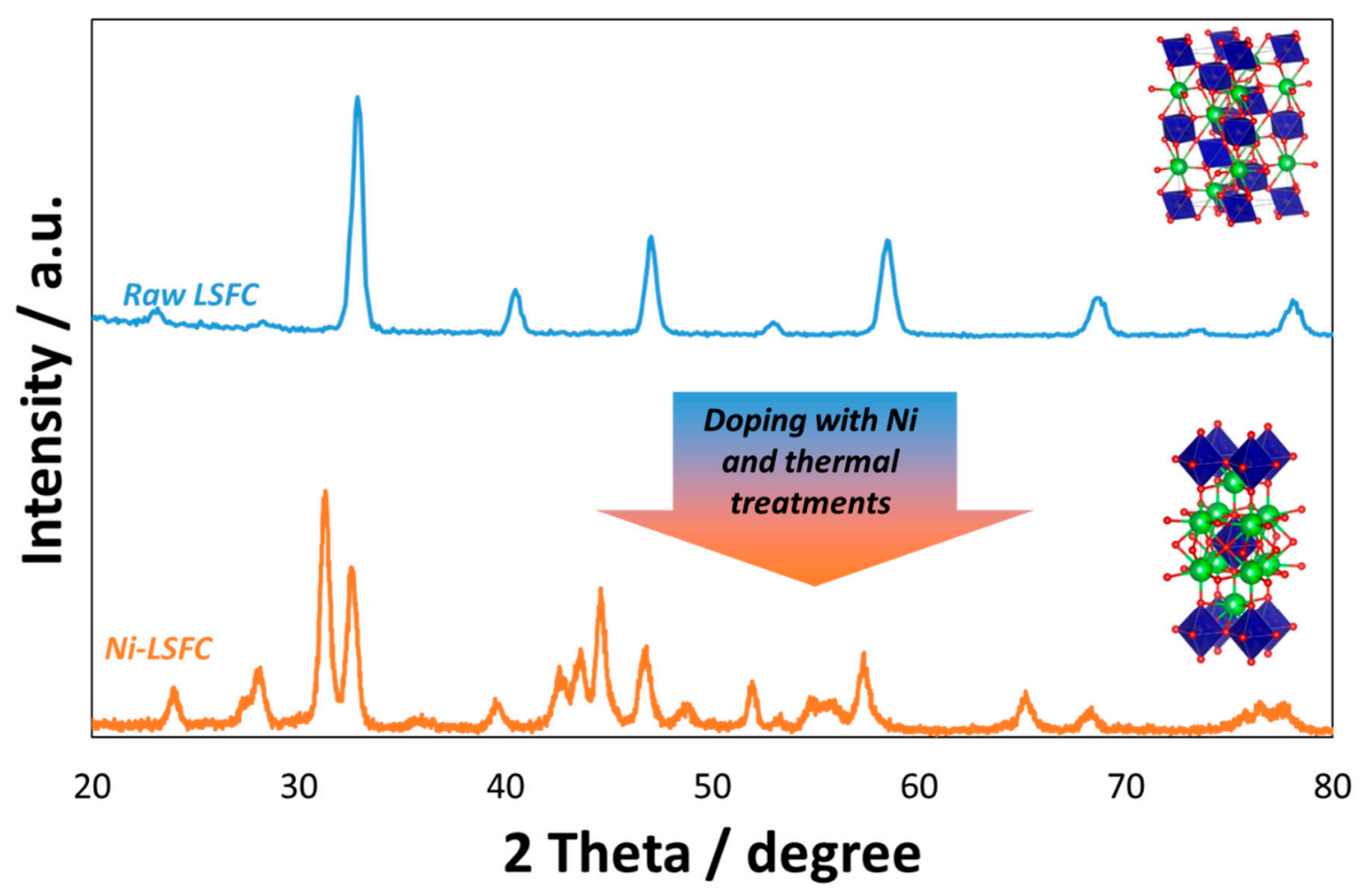

Figure 1. Structural analysis of raw (top) and modified (bottom) perovskites. The figure also reports the related unit cells. As shown, the addition of $\mathrm{Ni}$ and subsequent thermal treatments (calcination at $500{ }^{\circ} \mathrm{C}$ and reduction at $800^{\circ} \mathrm{C}$ ) caused the intercalation of one rocksalt-type phase into the perovskite ( $\mathrm{n}=1$ Ruddlesden-Popper phase).

The redox properties of these modified perovskites and their exsoluted fine particles have been the object of specific studies [57]. Figure 2 shows the temperature-programmed reduction (TPR) profile of Ni-LSFC/CGO (i.e., $\mathrm{Ce}_{0.8} \mathrm{Gd}_{0.2} \mathrm{O}_{2-\mathrm{d}}$ ), the HR-TEM image of a fine particle encapsulated in the surface of the catalyst and its EDX analysis. As discussed, Co and Fe were alloyed with Ni and migrated to the surface of perovskite as proved by the EDX analysis carried out during high-angle annular dark-field (HAADF) imaging, whereas an oxide shell was confirmed by the combination of EDX and HR-TEM analysis. This peculiar structure imparts to the material outstanding catalytic properties $[73,74]$. The TPR profile showed three signals in the temperature range of $300-650{ }^{\circ} \mathrm{C}$ related to the chemisorption of $\mathrm{H}_{2}$ on $\mathrm{Co}\left(\alpha_{1}\right.$ [75]), Fe ( $\alpha_{2}$ [76]), and $\mathrm{Ni}\left(\alpha_{3}\right.$ [77]). This indicates that the oxide surface of these nanoparticles turns into a trimetallic system under operation in reducing conditions at high temperature. The TPR profile showed also a broad peak around $650{ }^{\circ} \mathrm{C}$, which is due to the reduction of $\mathrm{Ce}\left(\mathrm{Ce}^{4+} \rightarrow \mathrm{Ce}^{3+}, \alpha_{4}[78,79]\right)$. Based on the XPS studies [62], the most probable oxidation states of metals for the fine embedded particles was $3^{+}$for both the cobalt and the iron and $2^{+}$for the nickel. By integrating the three TPR peaks observed in the temperature range between 300 and $650{ }^{\circ} \mathrm{C}$, the following composition $\alpha-\mathrm{Fe}_{23} \mathrm{Co}_{15} \mathrm{Ni}_{12} \mathrm{O}_{\mathrm{x}}$ is derived, suggesting an excess of iron in line with the evidence of the EDX profile. 


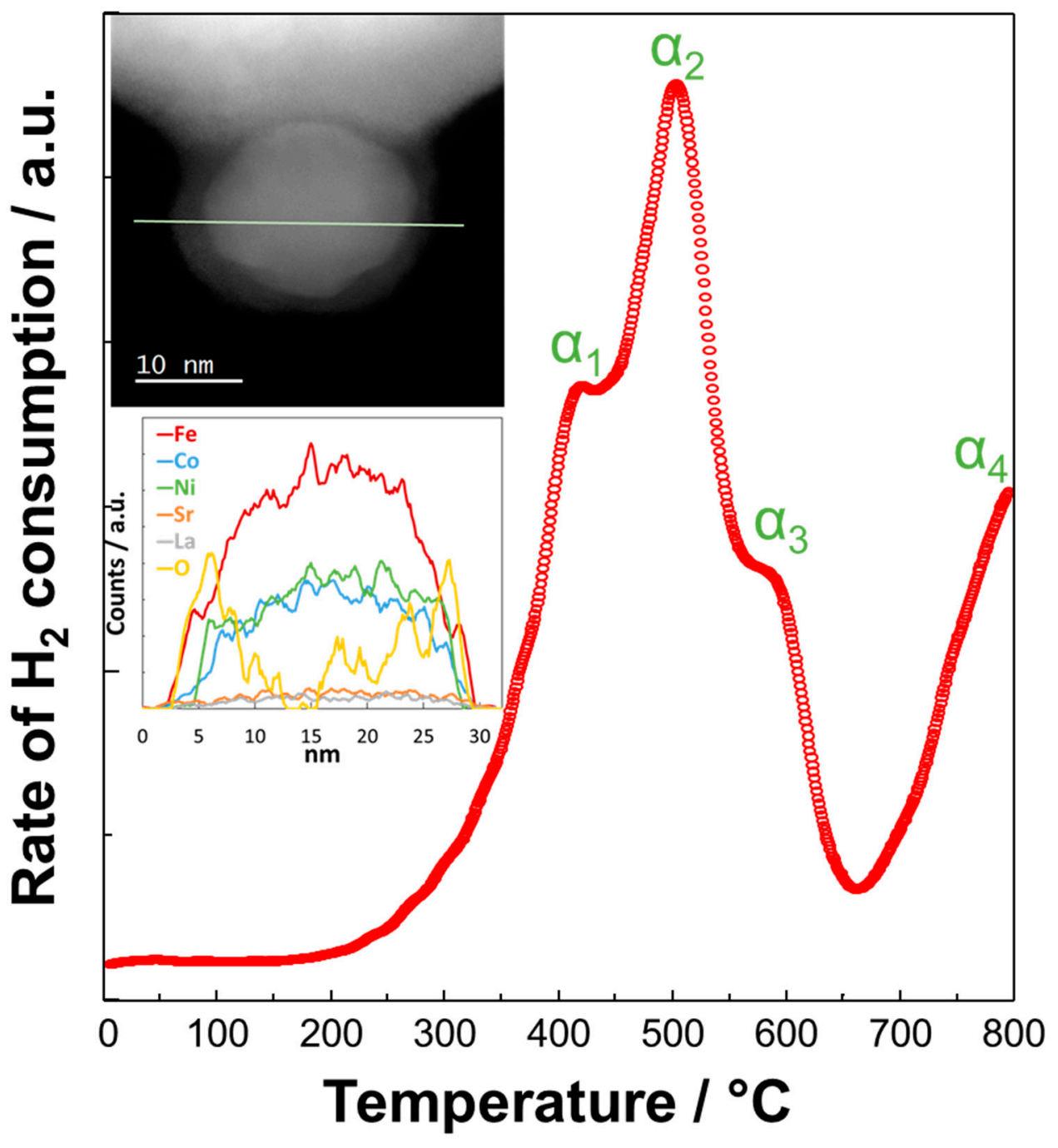

Figure 2. Temperature-programmed reduction (TPR) profile of Ni-LSFC/CGO, TEM image, and the Energy-Dispersive X-ray (EDX) measure carried out along the profile of an embedded nanoparticle on the surface of a modified perovskite. CGO: LSFC: $\mathrm{La}_{0.6} \mathrm{Sr}_{0.4} \mathrm{Fe}_{0.8} \mathrm{Co}_{0.2} \mathrm{O}_{3}$.

Generally, the surface area of these exsolved perovskite materials is $5.51 \mathrm{~m}^{2} \mathrm{~g}^{-1}$ as evaluated by Brunauer-Emmett-Teller (BET) analysis with mesoporous morphology [58]. Thus, the formation of fine embedded particles does not promote a significant increase of the overall surface roughness for the modified perovskite catalyst; instead, the initial surface area is quite similar (e.g., $5.2 \mathrm{~m}^{2} \mathrm{~g}^{-1}$ ).

\section{Catalytic Studies}

As this catalyst was suggested for the electrochemical conversion of organic fuels in SOFCs, preliminary catalytic tests have been carried out to collect information concerning its reliability toward the most common reactions occurring in the anode compartment of an SOFC during its operation. It has been largely reported that the most frequent reactions occurring at the anode compartment fed with organic fuels can be simulated ex situ by the autothermal reaction (ATR) [80,81]. In particular, water besides $\mathrm{CO}_{2}$ is formed during the oxidation of organic fuels and oxygen is provided at the electrolyte-anode interface. Nevertheless, some specific differences exist between the ATR reaction and the electrochemical reaction. This essentially concerns the fact that molecular oxygen is supplied during the ATR, whereas ionic oxygen is involved in the redox process. Thus, the net reactions of an electrochemical process and ATR reaction are similar but with the difference that the electrochemical reaction involves ionic oxygen and the release of electrons into the external circuit. It has been discussed 
in the literature that an SOFC may be fed with oxygen or water in combination with organics in order to minimize the risks associated with the carbon fibers' deposition (i.e., Partial Oxidation Reaction (POX) [82,83], Steam Reforming (SR) [82,84], and a combination of dry reforming and ATR named as tri-reforming $[85,86]$, respectively). Although a right balance of the stoichiometry may effectively minimize this risk, other aspects associated to the dilution of fuel, lower efficiency, and re-oxidation of the anode have been suggested to avoid the in situ supply of molecular oxygen $[4,84,87-90]$.

Generally, the risk of damaging an SOFC increases with the increasing of the carbon atoms in the fuel molecule. This can be mitigated by varying the steam-to-carbon and oxygen-to-carbon ratios. Therefore, the catalytic behavior of the exsolved perovskite materials has been preliminarily investigated under POX, SR, and ATR of methane [59], methanol [58], propane [59], and glycerol [57]. According to such previous studies, their reactivity toward oxidation follows this trend: methanol $>$ ethanol $>$ propane $>$ glycerol $>$ methane (Table 1). In particular, it has been shown [59] that methane did not reach much at $800{ }^{\circ} \mathrm{C}$, whereas other organics showed a significant production of syngas, with an $\mathrm{H}_{2} / \mathrm{CO}$ ratio that varied according to the $\mathrm{H} / \mathrm{C}$ ratio in the fuel. The same work also reported that the presence of unreacted fragments (i.e., $\mathrm{CH}_{4}$ ) was dependent on the molecular weight of the fuel. In addition, contrary to what was reported in the literature for the propensity of LSFC to catalyze the oxidative coupling of methane [54], no C2 compound has been detected in the outlet stream.

Table 1. Survey of the average product formation achieved in different reaction processes at $800{ }^{\circ} \mathrm{C}$. Data from [57-60].

\begin{tabular}{|c|c|c|c|c|c|c|c|c|c|}
\hline & & $\begin{array}{c}\mathrm{H}_{2} \\
\%\end{array}$ & $\begin{array}{c}\mathrm{CO} \\
\%\end{array}$ & $\underset{\%}{\mathrm{CO}_{2}}$ & $\underset{\%}{\mathrm{CH}_{4}}$ & $\mathrm{C}_{2} \mathrm{H}_{4} \%$ & $\mathrm{C}_{3} \mathrm{H}_{8} \%$ & $\begin{array}{c}\text { Others } \\
\%\end{array}$ & $\begin{array}{l}\text { Selectivity to } \\
\text { Syngas \% }\end{array}$ \\
\hline $\mathrm{SR}-800^{\circ} \mathrm{C}$ & Glycerol $(\mathrm{S} / \mathrm{C}=0.2)[57]$ & 29.45 & 28.39 & 32.90 & 7.50 & 1.76 & - & - & - \\
\hline $\mathrm{SR}-800^{\circ} \mathrm{C}$ & Glycerol (S/C = 2) [57] & 80.79 & 5.60 & 2.36 & 5.82 & 5.43 & - & - & - \\
\hline ATR- $800{ }^{\circ} \mathrm{C}$ & $\begin{array}{c}\text { Methane } \\
(\mathrm{S} / \mathrm{C}=2.5 ; \mathrm{O} / \mathrm{C}=0.5)[59]\end{array}$ & 5.95 & 2.19 & 1.62 & 85.68 & - & - & - & - \\
\hline ATR- $800{ }^{\circ} \mathrm{C}$ & $\begin{array}{c}\text { Methanol } \\
(\mathrm{S} / \mathrm{C}=2.5 ; \mathrm{O} / \mathrm{C}=0.5)[58,59]\end{array}$ & 67.44 & 13.73 & 17.71 & 0.56 & - & - & - & 87.42 \\
\hline ATR- $800{ }^{\circ} \mathrm{C}$ & $\begin{array}{c}\text { Propane } \\
(\mathrm{S} / \mathrm{C}=2.5 ; \mathrm{O} / \mathrm{C}=0.5)[59,60]\end{array}$ & 66.59 & 17.40 & 4.94 & 6.98 & 2.35 & 0.97 & 0.77 & - \\
\hline ATR- $800{ }^{\circ} \mathrm{C}$ & $(\mathrm{S} / \mathrm{C}=2.5 ; \mathrm{O} / \mathrm{C}=0.5)[59]$ & 31.10 & 29.62 & 29.01 & 9.56 & - & - & - & - \\
\hline SR- $800{ }^{\circ} \mathrm{C}$ & Methanol $(S / C=2.5)[58]$ & - & - & - & - & - & - & - & 81.70 \\
\hline POX $-800^{\circ} \mathrm{C}$ & Methanol $(\mathrm{O} / \mathrm{C}=0.5)[58]$ & - & - & - & - & - & - & - & 92.02 \\
\hline $\mathrm{SR}-800^{\circ} \mathrm{C}$ & Propane $(S / C=2.5)[60]$ & 64.59 & 15.04 & 9.34 & 6.75 & 1.99 & 1.48 & 0.81 & - \\
\hline $\mathrm{POX}-800{ }^{\circ} \mathrm{C}$ & Propane $(\mathrm{O} / \mathrm{C}=0.5)[60]$ & 43.73 & 29.20 & 0.68 & 13.03 & 10.06 & 1.68 & 1.62 & - \\
\hline ATR- $800^{\circ} \mathrm{C}$ & $\begin{array}{c}\text { Propane }(\mathrm{S} / \mathrm{C}=2.5 ; \mathrm{O} / \mathrm{C}=0.5) \\
+20 \mathrm{ppm} \mathrm{H}_{2} \mathrm{~S}[60]\end{array}$ & 22.38 & 8.73 & 18.76 & 15.48 & 28.57 & 6.18 & - & - \\
\hline ATR- $800{ }^{\circ} \mathrm{C}$ & $\begin{array}{c}\text { Propane }(\mathrm{S} / \mathrm{C}=2.5 ; \mathrm{O} / \mathrm{C}=0.5) \\
+40 \mathrm{ppm} \mathrm{H}_{2} \mathrm{~S}[60]\end{array}$ & 23.97 & 10.29 & 18.07 & 16.28 & 25.02 & 6.37 & - & - \\
\hline ATR- $800{ }^{\circ} \mathrm{C}$ & $\begin{array}{l}\text { Propane }(\mathrm{S} / \mathrm{C}=2.5 ; \mathrm{O} / \mathrm{C}=0.5) \\
\quad+60 \mathrm{ppm} \mathrm{H}_{2} \mathrm{~S}[60]\end{array}$ & 14.41 & 10.62 & 19.75 & 15.91 & 26.38 & 10.14 & 2.79 & - \\
\hline ATR- $800{ }^{\circ} \mathrm{C}$ & $\begin{array}{c}\text { Propane }(\mathrm{S} / \mathrm{C}=2.5 ; \mathrm{O} / \mathrm{C}=0.5) \\
+80 \mathrm{ppm} \mathrm{H}_{2} \mathrm{~S}[60]\end{array}$ & 13.25 & 8.76 & 19.60 & 16.55 & 29.06 & 12.74 & 0.04 & - \\
\hline
\end{tabular}

Specific works in the literature have addressed the stability of the perovskite in the presence of sulfur contaminants. Exsolved perovskite was investigated for the ATR of propane in the presence of $\mathrm{H}_{2} \mathrm{~S}$ up to $80 \mathrm{ppm}$. These studies [60] showed that the increase of sulfur in the feed caused a depletion of $\mathrm{H}_{2}$ in the produced syngas and a decrease of propane conversion, since $\mathrm{H}_{2} \mathrm{~S}$ has blocked the active sites of the electrocatalyst. Nevertheless, the overall negative effects caused by the $\mathrm{H}_{2} \mathrm{~S}$ appeared to be reversible, since the spent catalysts did not show any significant changes in their structure as revealed by XRD as well as limited amount of carbon and sulfur contents was detected through the elemental analysis (CHNS-O). In principle, the catalysts could be regenerated by proper activation.

\section{Electrochemical Studies}

According to the ex situ catalytic studies, the modified perovskites appear to be promising catalysts for application in a fuel-flexible SOFC. This hypothesis is supported by the different electrochemical behavior of LSFC and Ni-LSFC toward the electrochemical oxidation of dry propane [56]. This material 
has been investigated extensively in two main cell configurations consisting of a single fuel electrode supported on three different types of supporting electrolytes (e.g., CGO [56], $\mathrm{La}_{0.8} \mathrm{Sr}_{0.2} \mathrm{Ga}_{0.8} \mathrm{Mg}_{0.2} \mathrm{O}_{3}$ (LSGM) [61], and $\mathrm{BaCe}_{0.9} \mathrm{Y}_{0.1} \mathrm{O}_{3-\delta}(\mathrm{BYCO})$ ) and as a functional layer (pre-layer) for the anode of a commercial type cell (ASC-400B, ELCOGEN [62,63]). In the latter case, the SOFC consists of a dual-anode configuration where the modified perovskite acts as a catalytic pre-layer for the conversion of the organic molecules before these can reach the supporting Ni-YSZ anode.

The electrochemical experiments for the modified perovskite-based SOFC, carried out in $\mathrm{H}_{2}$, are reported in Figure 3a,b. The polarization curves (Figure 3a) reveal that the highest performance has been achieved by using the exsolved perovskite as a protective or pre-layer layer in an anode-supported cell configuration. The latter was based on the ASC-400B-Elcogen commercial cell simply modified by coating the exsolved perovskite on the outer anode surface. The highest performance achieved with the modified Elcogen cell is essentially due to a combination of lower ohmic constrain and higher open circuit voltage (OCV). Limited ohmic losses were also observed for the test carried out with a CGO electrolyte-supported cell (series resistance, Rs $=0.214 \mathrm{ohm} \mathrm{cm}^{2} @ 0.7 \mathrm{~V}$ for a dense electrolyte of a thickness of about $250 \mu \mathrm{m}$ ). However, in this case, the maximum achievable performance was limited by the low OCV. The latter was due to the mixed conductivity phenomenon of CGO, which corresponds to an internal current drag [91]. A different behavior was observed for the LSGM supporting cell. In this case, the achieved OCV was even higher than the thermodynamic value for water splitting at $800^{\circ} \mathrm{C}$. This aspect has been attributed to an additional oxygen pump effect that adds about 100 $\mathrm{mV}$ to the theoretical Nernst potential for the main reaction [92]. Despite this advantageous OCV value, the achieved performance was affected by a slight higher ohmic resistance (Rs $=0.32 \mathrm{ohm} \mathrm{cm}{ }^{2}$ @ $0.7 \mathrm{~V}$ achieved with a dense electrolyte of a thickness of about $300 \mu \mathrm{m}$ ). Such lower performances for the electrolyte-supported SOFCs can be mitigated by reducing the electrolyte thickness, since the oxygen ion conductivities of CGO and LSGM are similar and better than the YSZ used in the Elcogen-modified cell $[8,61,93]$. However, this should not occur at the expense of the mechanical robustness. It is pointed out that the thickness of the overall anode-supported Elecogen cell is much larger than the electrolyte-supported cells. However, the excellent electronic conductivity of the anode support avoids the occurrence of relevant ohmic losses.
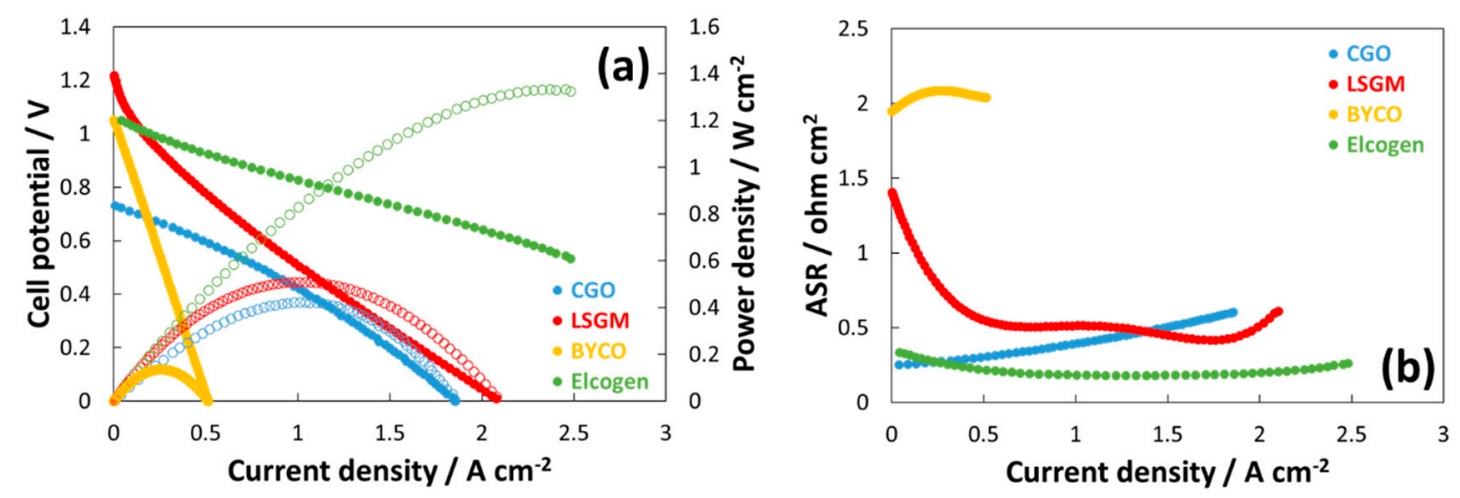

Figure 3. Polarization and ASR curves at $800{ }^{\circ} \mathrm{C}$ for the modified perovskite-based cells fed with $\mathrm{H}_{2}$ using three supporting electrolyte based Solid Oxide Fuel Cells (SOFCs) (e.g., CGO, LSGM, and BYCO) and a commercial Elcogen cell coated at the anode with an exsolved perovskite pre-layer. (a) Cell potential and power densities vs. current density; (b) area specific resistance vs. current density. (Standard deviation was $<7 \mathrm{mV}$ for each data point of the overall polarization dataset).

Another positive aspect associated with the use of LSGM consists of the possibility of achieving a proper mechanical and chemical compatibility with the exsolved perovskite being characterized by a similar structure and allowing the formation of a complete perovskite structure-based cell [61]. The polarization curve obtained with a protonic BYCO electrolyte indicates a proper OCV denoting an optimal sealing of cell and the presence of additional oxygen conductivity for this electrolyte. 
In this case, no electronic drag associated to the redox behavior of cerium species occurs, since Ce $\mathrm{e}^{4+}$ is stabilized in the orthorhombic phase of the perovskite [94,95]. However, the performance achieved for the BYCO-based cell was strongly affected by large ohmic losses $\left(1.44 \mathrm{ohm} \mathrm{cm}^{2} @ 0.7 \mathrm{~V}\right.$ for a dense electrolyte with a thickness of about $300 \mu \mathrm{m}$ ). This was in part due to the carbonation reaction of $\mathrm{Ba}$ generally occurring during the severe thermal treatment needed for its densification (above $1300^{\circ} \mathrm{C}$ ), which promotes the formation of an insulating phase [96,97]. Figure $3 b$ shows the first derivate of the I-V curves of Figure $3 a$, highlighting the change of area surface resistance versus the current density. It is noteworthy that the typical activation control at low current density is almost absent for all experiments except for the case of the experiment carried out with the LSGM electrolyte. In this case, a fast decrease of resistance occurred during the first $300 \mathrm{~mA} \mathrm{~cm}^{-2}$, and this is due to the extra potential (about $100 \mathrm{mV}$ ) caused by the oxygen pump effect discussed above. By observing the Area Specific Resistance (ASR) curve of the experiment carried out by the BYCO electrolyte, a stable and high resistance constraint was observed, confirming the evidences reported above. According to these experiments, the exsolved perovskite may be properly used as an anode for SOFCs fed with $\mathrm{H}_{2}$ provided it is combined with a proper electrolyte material. In the case of the Elcogen-modified cell, a peak power density of $1.4 \mathrm{~W} \mathrm{~cm}^{-2}$ is achieved, whereas at $0.8 \mathrm{~V}$, the current density largely exceeds $1 \mathrm{~W} \mathrm{~cm}^{-2}$.

However, the modified perovskite catalysts have been mainly developed for the electro-oxidation of organic compounds with the aim to develop a fuel-flexible SOFC cell. Experiments reported in the literature have concerned the use of dry fuels (e.g., methane, syngas, methanol, ethanol, propane, and glycerol). Polarization curves for the modified perovskite-based cells directly fed with various organic fuels are shown in Figure $4 a, b$. One of the first reports addressing fuel flexibility was published in 2012 [59]. Electrochemical tests dealing with the direct oxidation of various dry organic fuels were carried out for about $130 \mathrm{~h}$ without any relevant evidence of carbon formation. Figure $4 \mathrm{a}$ shows the cell performance behavior for the direct oxidation of several organic fuels using a thick $(250 \mu \mathrm{m})$ CGO-electrolyte-supported cell containing a modified perovskite anode. The best performance is achieved for syngas, propane, and methanol, whereas low performance is observed for methane. However, despite the large thickness of the supporting electrolyte, the influence of the internal redox properties of the ceria-based electrolyte $\left(\mathrm{Ce}^{4+} \rightarrow \mathrm{Ce}^{3+}\right)$, in the presence of a reducing environment at the anode, dominates the polarization behavior. As expected, the most effective electronic state of Ce depends on the reducing environment. As a consequence, on the cathode, the oxidation state is $\mathrm{Ce}^{4+}$, whereas on the anode side, this is $\mathrm{Ce}^{3+}$. The migration of oxygen from the cathode to the anode has the effect of moving the equilibrium between these two oxidized states of Ce. This mechanism corresponds to an internal chemical "short circuit" for the CGO electrolyte.
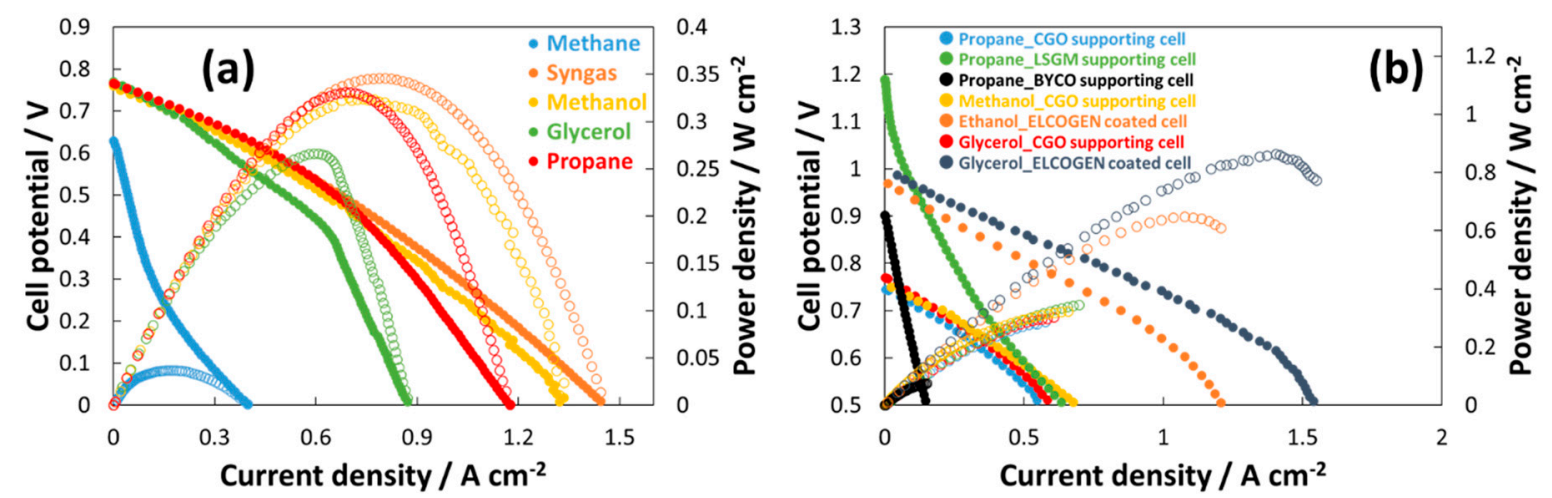

Figure 4. Polarization curves for the modified perovskite-based cells operating in multifuel mode in the presence of a thick supported CGO electrolyte (a) adapted from [59] and with different organic fuels and cell designs (b) adapted from [56-58,61-63]. (Standard deviation was $<5 \mathrm{mV}$ for each data point of the overall polarization dataset). 
As a consequence, the observed OCV values are below $1 \mathrm{~V}$ for all experiments shown in Figure $4 \mathrm{a}$ denoting an internal electronic drag due to the CGO redox properties [91], as discussed above. Moreover, the performances are also negatively affected by the thickness of the CGO electrolyte.

The low performance achieved in the presence of dry methane is related to a poor reactivity of this molecule over the modified perovskite surface as corroborated by the low OCV. In this case, the polarization curve is strongly affected by both activation and ohmic constrains. Differently from other organic fuels, direct methane oxidation appears quite difficult at the perovskite surface as confirmed by ex situ catalytic tests carried under authothermal reforming (ATR) mode for methane [59].

Despite these limitations, the overall stability shown by this cell configuration during endurance tests with dry organic fuels was promising and prompted further investigation with more appropriate cell designs. Figure $4 \mathrm{~b}$ summarizes some polarization curves achieved with different dry organic fuels and cell designs all based on modified perovskite anodes. One can observe that the cell designs can dramatically affect the performance. Ceria-based electrolytes show poor performance as a consequence of the significant electronic drag and low OCV, while the anode-supported cell with thin YSZ electrolyte shows the best performance even if the OCV is slightly lower than that of the equivalent cells fed with hydrogen, supporting the notion that LSGM electrolyte-based cells show excellent OCV but strong ohmic losses. Thus, the most appropriate approach is to coat Ni-YSZ anode-supported cells with a modified or exsolved perovskite pre-layer (protecting layer or conducive catalytic layer). This can enhance fuel flexibility without relevant modifications of the SOFC technology.

For most of the cell configurations, maximum power densities are achieved at a potential of around $0.5 \mathrm{~V}$. This voltage is generally considered as the lower potential limit for SOFC operation. At lower voltages, the overall efficiency is dramatically affected by the reduced voltage efficiency. This indicates that further efforts should be addressed to improve the voltage efficiency of dry organic fuel-fed SOFC cells by further amelioration of the modified perovskite properties. Moreover, it is necessary to acquire more insights into the poor reaction kinetics of methane oxidation at the perovskite catalyst surface to improve the anode characteristics.

Several experiments carried out with organic fuels are summarized in Table 2. In one case, the exsolved perovskite has been studied for $780 \mathrm{~h}$ in the presence of a large excess of dry propane observing a decay of $1.1 \times 10^{-4} \mathrm{~A} \mathrm{~h}^{-1}$. In principle, a large excess of fuel suppresses the partial pressure of water and $\mathrm{CO}_{2}$ formed during the electrochemical reaction occurring at the anode. As a consequence, the wet and dry reforming reactions are limited, and the reactions causing the cracking of the organic fuel become largely probable. The open circuit voltage condition appears to be the most stressful situation for the anode when this is fed with organic fuels. Therefore, a demonstration of SOFC stability for a time exceeding $100 \mathrm{~h}$ under this condition is considered to be a very promising result.

Prolonged operation has not damaged the SOFC cell as well as the anode, and there was no significant occurrence of carbon deposits on the surface [56]. Significant advances have regarded the use of this electrocatalyst as a coating layer of a commercial-type cell fed directly with dry organic fuels such as ethanol and glycerol. The effective oxidation of these fuels has confirmed the perspective that this electrocatalyst may have potential for the simplification of this technology, in particular of the balance of the plant by reducing the fuel-processing steps. Since the approach, consisting of the use of a proper coating layer of modified perovskite on the anode, does not imply the modification of the SOFC production chain while making these devices fuel-flexible, a proper diffusion of this approach is envisaged in the next years. Regarding the role of CGO mixed to the perovskite electrocatalyst, a previous paper [56] has elucidated the promoting effect of this mixed ionic electronically conducting material for propane oxidation.

In general, various results have demonstrated a strong increase of electrocatalytic activity in the presence of the exsolved perovskite. However, the activity is essentially related to the molecule structure and reactivity with the best results obtained with ethanol and propane (Table 2). In particular, in the presence of methane in a test carried out with a CGO-supported cell, a very low performance 
has been obtained [59]. The possible reasons for this behavior have been discussed in light of the electrochemical and chromatographic analysis results.

Table 2. Resume of the most important results of the electrochemical tests carried out at $800{ }^{\circ} \mathrm{C}$ with different organic fuels. Data from [56-59,61-63].

\begin{tabular}{|c|c|c|c|c|c|c|}
\hline & $\begin{array}{c}\text { Type of } \\
\text { Cell/Electrolyte }\end{array}$ & 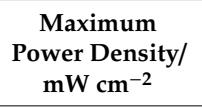 & $\begin{array}{l}\text { Series } \\
\text { Resistance } \\
/ \Omega \mathrm{cm}^{-2}\end{array}$ & $\begin{array}{c}\text { Total } \\
\text { Resistance } \\
/ \Omega \mathrm{cm}^{-2}\end{array}$ & $\begin{array}{c}\text { Maximum } \\
\text { Durability } \\
\text { Demonstrated/h }\end{array}$ & $\begin{array}{c}\text { Average Decay } \\
\text { during the Life } \\
\text { Time Test/A } \mathbf{h}^{-1}\end{array}$ \\
\hline Methane [59] & $\begin{array}{c}\text { CGO } \\
(250 \mu \mathrm{m})\end{array}$ & $37 @ 0.22 \mathrm{~V}$ & $0.51 @ 0.5 \mathrm{~V}$ & $2.78 @ 0.5 \mathrm{~V}$ & 15 & 0 \\
\hline Syngas [58] & $\begin{array}{c}\text { CGO } \\
(250 \mu \mathrm{m})\end{array}$ & $346 @ 0.44 \mathrm{~V}$ & $0.24 @ 0.765$ V & $0.29 @ 0.765 \mathrm{~V}$ & $17[59]$ & 0 \\
\hline Methanol [58] & $\begin{array}{c}\text { CGO } \\
(250 \mu \mathrm{m})\end{array}$ & $358 @ 0.47 \mathrm{~V}$ & $0.26 @ 0.75 \mathrm{~V}$ & $0.33 @ 0.75 \mathrm{~V}$ & $18[59]$ & $410^{-3}$ \\
\hline Ethanol [62] & Elcogen & $648 @ 0.60 \mathrm{~V}$ & $0.18 @ 0.7 \mathrm{~V}$ & $0.46 @ 0.7 \mathrm{~V}$ & 400 & $1.510^{-4}$ \\
\hline Propane [56] & $\begin{array}{c}\text { CGO } \\
(250 \mu \mathrm{m})\end{array}$ & $288 @ 0.51 \mathrm{~V}$ & $0.25 @ 0.5 \mathrm{~V}$ & $0.33 @ 0.5 \mathrm{~V}$ & 780 & $1.110^{-4}$ \\
\hline Propane [61] & $\begin{array}{l}\text { LSGM } \\
(300 \mu \mathrm{m})\end{array}$ & $328 @ 0.43 \mathrm{~V}$ & $0.32 @ 0.7 \mathrm{~V}$ & $0.92 @ 0.7 \mathrm{~V}$ & 15 & $510^{-4}$ \\
\hline Glycerol [57] & $\begin{array}{c}\text { CGO } \\
(250 \mu \mathrm{m})\end{array}$ & $320 @ 0.46 \mathrm{~V}$ & $0.30 @ 0.5 \mathrm{~V}$ & $0.66 @ 0.5 \mathrm{~V}$ & 19 [59] & 0 \\
\hline Glycerol [63] & Elcogen & $864 @ 0.62 \mathrm{~V}$ & $0.12 @ 0.7 \mathrm{~V}$ & $0.25 @ 0.7 \mathrm{~V}$ & 157 & $110^{-3}$ \\
\hline
\end{tabular}

\section{Reaction Mechanism}

One important aspect of the previous studies carried out on modified perovskite electrocatalysts has regarded the reaction mechanisms involving the direct oxidation of dry organic fuels [62,63]. Figure 5 depicts the mechanisms suggested for the electrochemical conversion of ethanol. The oxidation of dry ethanol appears to proceed through multiple and consequent reactions. These involve dehydrogenation (Equations (1)-(3)) and decomposition (Equation (4)) steps with a consequent electrochemical oxidation of $\mathrm{H}_{2}$ (Equation (5)) and $\mathrm{CO}$ (Equation (6)) to form water and $\mathrm{CO}_{2}$, respectively.

The complete process is described below:

$$
\begin{gathered}
\mathrm{CH}_{3} \mathrm{CH}_{2} \mathrm{OH} \stackrel{\text { Ni-Perovskite/CGO }}{\longrightarrow}-\mathrm{CH}_{2_{\text {ads }}}+\mathrm{CO}+2 \mathrm{H}_{2} \\
\mathrm{CH}_{3} \mathrm{CH}_{2} \mathrm{OH} \stackrel{\text { Ni-Perovskite/CGO }}{\longrightarrow} \mathrm{CH}_{3} \mathrm{CHO}+\mathrm{H}_{2} \\
\mathrm{CH}_{3} \mathrm{CHO} \stackrel{\text { Ni-Perovskite/CGO }}{\longrightarrow} \mathrm{CH}_{4}+\mathrm{CO} \\
\mathrm{H}_{2} \mathrm{O}+-\mathrm{CH}_{2_{\text {ads }}} \stackrel{\text { Ni-Perovskite } / \mathrm{CGO}}{\longrightarrow} 2 \mathrm{H}_{2}+\mathrm{CO} \\
2 \mathrm{H}_{2}+2 \mathrm{O}^{2-} \stackrel{\text { Ni-YSZ }}{\longrightarrow} 2 \mathrm{H}_{2} \mathrm{O}+4 \mathrm{e}^{-} \\
2 \mathrm{CO}+2 \mathrm{O}^{2-} \stackrel{\text { Ni-YSZ}}{\longrightarrow} 2 \mathrm{CO}_{2}+4 \mathrm{e}^{-} .
\end{gathered}
$$

The latter processes occur at the triple phase boundaries of the Ni-YSZ anode. This mechanism has been named a "shuttle mechanism" to indicate the migration of $\mathrm{H}_{2}$ and $\mathrm{CO}$, which are produced at the pre-catalytic layer according to an internal reforming step, to the interface and their return to the pre-catalytic layer as $\mathrm{H}_{2} \mathrm{O}$ and $\mathrm{CO}_{2}$ favoring the fuel processing. The side reforming reactions involving water and $\mathrm{CO}_{2}$ also play a role even if to a lower extent in the presence of an excess of fuel. Such a shuttle mechanism has been suggested based on a combination of chromatographic and HPLC (high-performance liquid chromatography) studies carried out on the gaseous and liquid products for a cell operating with dry ethanol. These analyses have revealed the presence of acetaldehyde and acetic acid in addition to $\mathrm{CH}_{4}, \mathrm{CO}_{2}, \mathrm{H}_{2} \mathrm{O}$, and $\mathrm{CO}$. These evidences have proved that one of the possible rate-determining steps for this oxide catalyst regards the dehydrogenation. Therefore, it is largely probable that the cell fed with methane has shown lower performance, since its dehydrogenation is more difficult than that of other molecules. In addition, the oxidative coupling sometimes reported as a possible reaction catalyzed by perovskites [98] including the LSFC [54] may be reasonably neglected, 
since no carbon-based molecules with higher molecular weight than methane have been observed in the chromatographic analyses.

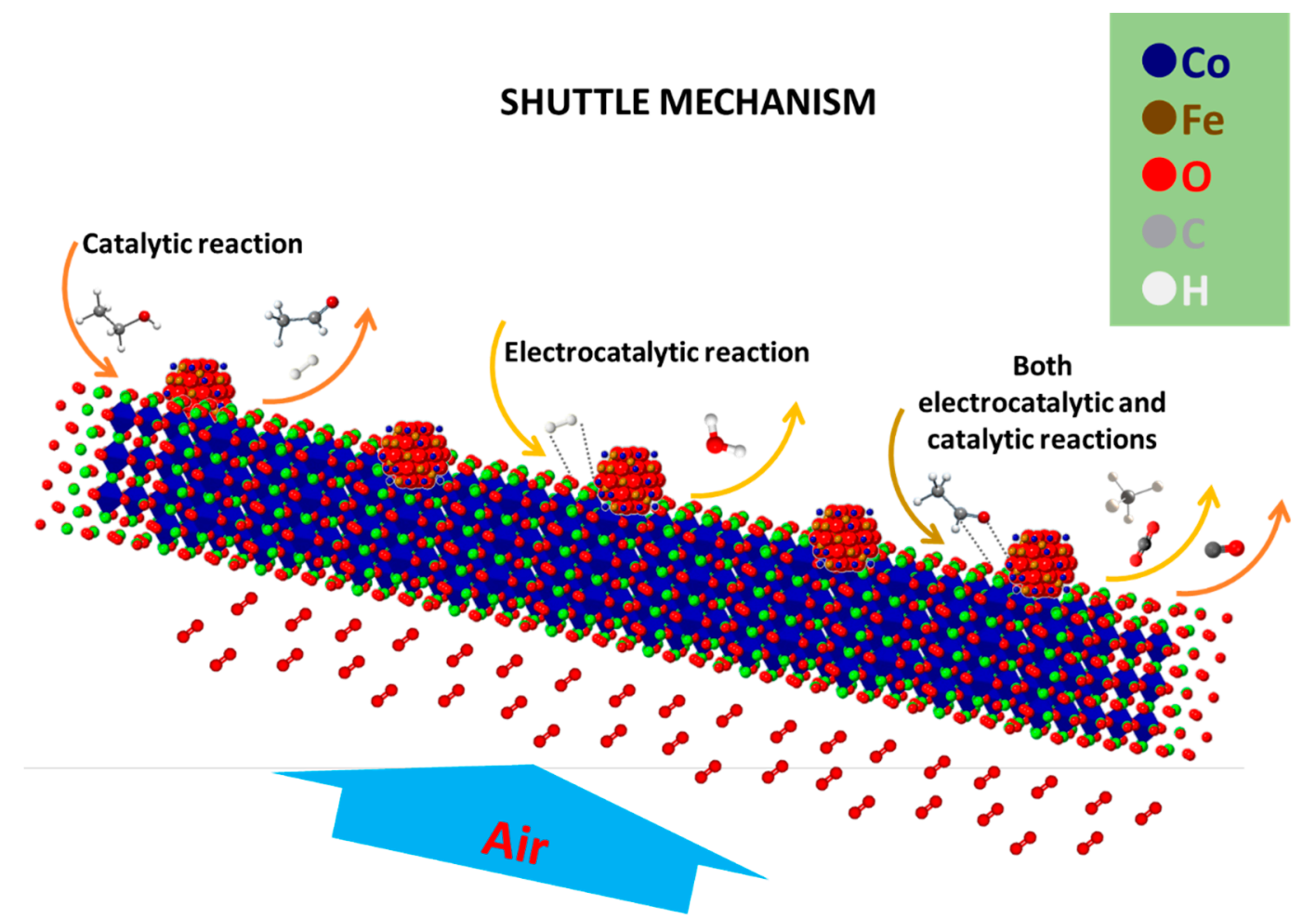

Figure 5. Exemplification of the shuttle mechanism suggested for dry ethanol fed at a modified perovskite-based SOFC cell. The support represents the exsolved perovskite, whereas the fine embedded particles are ascribed to the $\alpha-\mathrm{Fe} 100-\mathrm{y}-\mathrm{zCoyNizOx}$ oxide. Air is fed to the cathode, and oxygen ions migrate to the anode through the electrolyte.

\section{Key Insights on Challenges and Perspectives}

The ferrite-based perovskite used as a substrate for a pre-catalytic layer is currently a benchmark for the oxygen electrode in Solid Oxide Fuel Cells (SOFCs) and Solid Oxide Electrolysis Cells (SOECs) operating at intermediate temperature. Specific strengths are the lower cost and the lower constraints compared to the manganite-based perovskites [99-101]. Therefore, its use as a fuel electrode or as a promoter for an in situ fuel processor is highly desired [102]. However, this material is not sufficiently stable in a reducing environment [54,103]. It may become chemically stable upon reduction at high temperature and utilization at intermediate temperature. Moreover, as for the most perovskite, the rates for the electroxidation of $\mathrm{H}_{2}$ and organic fuels are low. A possible solution to this issue is the decoration with metallic-based particles as discussed above. Based on the experiments reported in the literature, the modified Ni-LSFC is a promising electrocatalyst for organic fuels that may be easily dehydrogenated at the very early stage of their oxidation. On the other hands, Ni-LSFC has shown strong limitations for the conversion of $\mathrm{CH}_{4}$. Several papers have discussed the use of Ni alloys as a possible electrocatalyst for the oxidation of light organic fuels such as methane [104-106]. This allows addressing the low reactivity of exsolved perovskites toward methane, making the pre-catalytic layer more suitable for a fuel-flexible SOFC. We have recently started the investigation of a novel exsolved LSFC by adding $30 \mathrm{wt} \%$ of a NiCu alloy (1:1 at.). This electrocatalyst was prepared with the same procedure as that mentioned above. A conventional anode-supported cell (Elcogen) modified with such composite catalyst has shown very promising performance and durability. The cell was fed with dry biogas (30 vol. \% $\mathrm{CO}_{2}$ and 70 vol. $\% \mathrm{CH}_{4}$ ), and it showed $>0.2 \mathrm{~W} \mathrm{~cm}^{-2}$ with biogas and a low decay during a lifetime test carried out at $650{ }^{\circ} \mathrm{C}$ for about $100 \mathrm{~h}$. 
Figure 6a shows the polarization curves achieved with this novel composite electrocatalyst. The cell has shown an OCV close to $1 \mathrm{~V}$ in the presence of biogas. The achieved cell performance approached $200 \mathrm{~mW} \mathrm{~cm}{ }^{-2}$ at $0.66 \mathrm{~V}$ with biogas. The curves seem to be affected only by ohmic constraints due to the intermediate temperature operation (i.e., $650^{\circ} \mathrm{C}$ ). Figure $6 \mathrm{~b}$ shows a durability time test at a current density of $150 \mathrm{~mA} \mathrm{~cm}{ }^{-2}$ with a high fuel flow rate (i.e., $5 \mathrm{cc} \mathrm{min}^{-1} \mathrm{~cm}^{2}$ ). The cell appears very stable under dry biogas feed and no carbon deposition is envisaged under these experimental conditions.
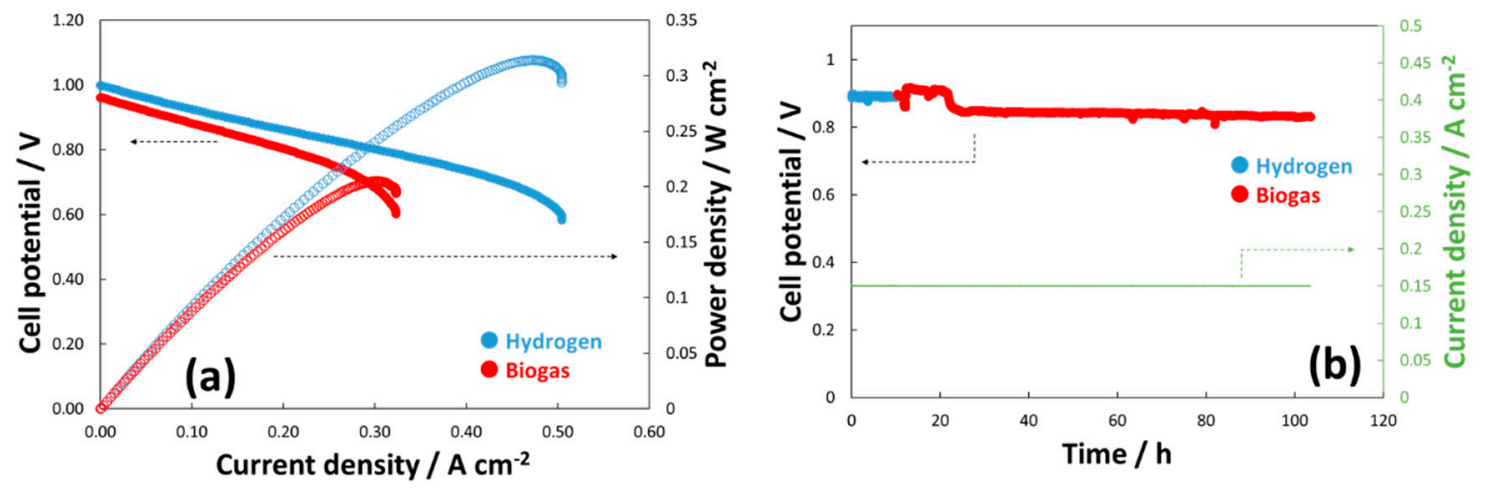

Figure 6. Polarization curves (a) and lifetime test (b) carried out with a novel NiCu-exsolved $\mathrm{La}_{0.6} \mathrm{Sr}_{0.4} \mathrm{Fe}_{0.8} \mathrm{Co}_{0.2} \mathrm{O}_{3}$ (LSFC) perovskite composite catalyst. These tests have been carried out at $650{ }^{\circ} \mathrm{C}$ with NiCu-LSFC coated on an Elcogen cell fed with $\mathrm{H}_{2}$ and biogas (30 vol.\% of $\mathrm{CO}_{2}$ ). (Standard deviation was $<5 \mathrm{mV}$ for each data point of the overall polarization dataset).

This novel approach should be evaluated in relation to the limited performance achieved for the Ni-LSFC fed with dry methane and reported in Figure 4a. As we discussed above, Ni-LSFC showed a low reactivity toward the oxidation of methane, and this is ascribed to the rate-determining step due to the dehydrogenation of this fuel. The present composite catalyst (NiCu-LSFC) registered an $\mathrm{OCV}$ close to $1 \mathrm{~V}$, which proves a high reactivity toward $\mathrm{CH}_{4}$. This is in line with the reactivity we have already demonstrated for various Ni-based alloys in several recent papers $[11,12,33,34,37,107]$. However, some mass transfer limitations at a cell voltage of about $0.6 \mathrm{~V}$ have been observed. This effect has a negative impact on the "shuttle mechanism", causing such voltage decay at sustained currents in the polarization curves.

\section{Conclusions}

The analysis presented in this mini-review deals with a number of studies carried out over more than a decade on a novel modified perovskite used as an anode electrocatalyst for application in fuel-flexible SOFCs. The exsolved perovskite shows the presence of fine embedded particles made of transition elements such as $\mathrm{Fe}, \mathrm{Ni}$, and $\mathrm{Co}$ over a depleted perovskite substrate. This structure is characterized by outstanding catalytic activity and proper electronic conductivity under reducing conditions. Moreover, a limited coarsening effect is generally observed for the embedded nanoparticles even upon prolonged operation. Catalytic and electrochemical studies have proved an effective capability of this material to convert organic fuels and good chemical stability under reducing conditions. These evidences make this electrocatalyst a promising anode for electrolyte-supported cells or as a coating layer for anode-supported cells. The exsolved perovskite catalyst can also be modified by the addition of an Ni alloy to form a composite layer. A specific "shuttle mechanism" is envisaged for the catalyst operation in an SOFC. This includes iterative adsorption and desorption steps involving the organic fuel and the reaction intermediates, the reaction at the interface of the formed hydrogen and carbon monoxide, with the final formation of water and $\mathrm{CO}_{2}$. This approach appears very promising for multifuel-fed SOFCs, and it is expected to attract large interest in the coming years. 
Author Contributions: Conceptualization, A.S.A. and M.L.F.; methodology, A.S.A. and S.C.Z.; software, M.L.F.; analysis, S.C.Z. and M.L.F.; investigation, S.C.Z.; writing-original draft preparation, M.L.F. and A.S.A.; writing-review and editing, M.L.F. and A.S.A.; project administration, A.S.A.; funding acquisition, A.S.A. All authors have read and agreed to the published version of the manuscript.

Funding: This research was funded by the Italian Ministry of Education, University and Research in the framework of PRIN2017 program and for the project entitled "Direct utilization of bio-fuels in solid oxide fuel cells for sustainable and decentralised production of electric power and heat (DIRECTBIOPOWER)" Grant Agreement number: 2017FCFYHK.

Conflicts of Interest: The authors declare no conflict of interest.

\section{Abbreviations}

\begin{tabular}{|c|c|}
\hline Acronym & Full form \\
\hline ASC & Anode Supporting Cell \\
\hline ASR & Area Specific Resistance \\
\hline ATR & Autothermal Reforming \\
\hline BET & Brunauer-Emmett-Teller surface area analysis \\
\hline $\mathrm{BYCO}$ & $\mathrm{BaCe}_{0.9} \mathrm{Y}_{0.1} \mathrm{O}_{3-\delta}$ \\
\hline CGO & $\mathrm{Gd}_{0.2} \mathrm{Ce}_{0.8} \mathrm{O}_{2-\mathrm{d}}$ \\
\hline CHNS-O & Carbon, Hydrogen, Nitrogen, Sulfur, Oxygen Elemental Analyzer \\
\hline EDX & Energy-dispersive X-ray spectroscopy \\
\hline LSFC & $\mathrm{La}_{0.6} \mathrm{Sr}_{0.4} \mathrm{Fe}_{0.8} \mathrm{Co}_{0.2} \mathrm{O}_{3}$ \\
\hline LSGM & $\mathrm{La}_{0.8} \mathrm{Sr}_{0.2} \mathrm{Ga}_{0.8} \mathrm{Mg}_{0.2} \mathrm{O}_{3}$ \\
\hline OCV & Open Circuit Voltage \\
\hline POX & Partial Oxidation Reaction \\
\hline SOFC & Solid Oxide Fuel Cells \\
\hline SR & Steam Reforming \\
\hline TPR & Temperature-Programmed Reduction \\
\hline XPS & X-ray Photoelectron Spectroscopy \\
\hline YSZ & Yttria-stabilized Zirconia \\
\hline HR-TEM & High-Resolution Transmission Electron Microscopy \\
\hline
\end{tabular}

\section{References}

1. Dong, Y.; Steinberg, M. Hynol—An economical process for methanol production from biomass and natural gas with reduced $\mathrm{CO}_{2}$ emission. Int. J. Hydrog. Energy 1997, 22, 971-977. [CrossRef]

2. Gibbs, C.E.; Steel, M.C.F. European opportunities for fuel cell commercialisation. J. Power Sources 1992, 37, 35-43. [CrossRef]

3. Lee, A.L.; Zabransky, R.F.; Huber, W.J. Internal reforming development for Solid Oxide Fuel Cells. Ind. Eng. Chem. Res. 1990, 29, 766-773. [CrossRef]

4. Bove, R.; Sammes, N.M. Thermodynamic analysis of SOFC systems using different fuel processors. In Proceedings of the ASME 2004 2nd International Conference on Fuel Cell Science, Engineering and Technology, Rochester, NY, USA, 14-16 June 2004; pp. 461-466.

5. Steele, B.C.H. Materials for IT-SOFC stacks-35 years R\&D: The inevitability of gradualness? Solid State Ion. 2000, 134, 3-20. [CrossRef]

6. La Rosa, D.; Lo Faro, M.; Monforte, G.; Antonucci, V.; Arico, A.S. Comparison of the electrochemical properties of intermediate temperature solid oxide fuel cells based on protonic and anionic electrolytes. J. Appl. Electrochem. 2009, 39, 477-483. [CrossRef]

7. Sauvert, A.L.; Fouletier, J. Research trends: Electrochemical properties of new type of IT-SOFC anode material. Fuel Cells Bull. 2002, 2002, 12.

8. Lo Faro, M.; La Rosa, D.; Antonucci, V.; Arico, A.S. Intermediate temperature solid oxide fuel cell electrolytes. J. Indian Inst. Sci. 2009, 89, 363-380.

9. Kikuchi, R.; Koashi, N.; Matsui, T.; Eguchi, K.; Norby, T. Novel anode materials for multi-fuel applicable solid oxide fuel cells. J. Alloy. Compd. 2006, 408, 622-627. [CrossRef] 
10. La Rosa, D.; Lo Faro, M.; Monforte, G.; Antonucci, V.; Arico, A.S.; Antonucci, P. Propane conversion over a $\mathrm{Ru} / \mathrm{CGO}$ catalyst and its application in intermediate temperature solid oxide fuel cells. J. Appl. Electrochem. 2007, 37, 203-208.

11. La Rosa, D.; Sin, A.; Lo Faro, M.; Monforte, G.; Antonucci, V.; Arico, A.S. Mitigation of carbon deposits formation in intermediate temperature solid oxide fuel cells fed with dry methane by anode doping with barium. J. Power Sources 2009, 193, 160-164. [CrossRef]

12. Lo Faro, M.; La Rosa, D.; Frontera, P.; Antonucci, P.; Antonucci, V.; Arico, A.S. Propane-fed Solid Oxide Fuel Cell based on a composite Ni-La-CGO anode catalyst. Catal. Lett. 2010, 136, 57-64. [CrossRef]

13. De Marco, V.; Iannaci, A.; Lo Faro, M.; Sglavo, V.M. Influence of Copper-based anode composition on intermediate temperature Solid Oxide Fuel Cells performance. Fuel Cells 2017, 17, 708-715. [CrossRef]

14. Escudero, M.J.; Yeste, M.P.; Cauqui, M.A.; Muñoz, M.A. Performance of a direct methane solid oxide fuel cell using nickel-ceria-yttria stabilized zirconia as the anode. Materials 2020, 13, 599. [CrossRef] [PubMed]

15. Gandiglio, M.; Lanzini, A.; Santarelli, M.; Acri, M.; Hakala, T.; Rautanen, M. Results from an industrial size biogas-fed SOFC plant (the DEMOSOFC project). Int. J. Hydrog. Energy 2020, 45, 5449-5464. [CrossRef]

16. Yokokawa, H.; Suzuki, M.; Yoda, M.; Suto, T.; Tomida, K.; Hiwatashi, K.; Shimazu, M.; Kawakami, A.; Sumi, H.; Ohmori, M.; et al. Achievements of NEDO durability projects on SOFC stacks in the light of physicochemical mechanisms. Fuel Cells 2019, 19, 311-339. [CrossRef]

17. Santhanam, S.; Ullmer, D.; Wuillemin, Z.; Varkaraki, E.; Beetschen, C.; Antonetti, Y.; Ansar, A. Experimental analysis of a $25 \mathrm{kWe}$ solid oxide fuel cell module for co-generation of hydrogen and power. Ecs Trans. 2019, 91, 159-166. [CrossRef]

18. McPhail, S.J.; Pumiglia, D.; Laurencin, J.; Hagen, A.; Leon, A.; Van Herle, J.; Vladikova, D.; Montinaro, D.; Piccardo, P.; Polverino, P.; et al. Developing accelerated stress test protocols for solid oxide fuel cells and electrolysers: The European project AD ASTRA. Ecs Trans. 2019, 91, 563-570. [CrossRef]

19. Wang, Q.; Wei, H.H.; Xu, Q. A solid oxide fuel cell (SOFC)-based biogas-from-waste generation system for residential buildings in China: A feasibility study. Sustainability 2018, 10, 2395. [CrossRef]

20. Stoeckl, B.; Subotić, V.; Preininger, M.; Schroettner, H.; Hochenauer, C. SOFC operation with carbon oxides: Experimental analysis of performance and degradation. Electrochim. Acta 2018, 275, 256-264. [CrossRef]

21. Maraver, D.; Tondi, G.; Goodchild, R. Overview and current status of eu funded actions on bio-fuelled heating and combined heating \& power within the energy challenge of Horizon 2020. In Proceedings of the 26th European Biomass Conference and Exhibition, Copenhagen, Denmark, 14-18 May 2018; pp. 1289-1298.

22. Montinaro, D.; Sglavo, V.M.; Bertoldi, M.; Zandonella, T.; Aricò, A.; Lo Faro, M.; Antonucci, V. Tape casting fabrication and co-sintering of solid oxide "half cells" with a cathode-electrolyte porous interface. Solid State Ion. 2006, 177, 2093-2097. [CrossRef]

23. Murata, K.; Shimotsu, M. Fabrication and evaluation of electrode-supported planar SOFC. Denki Kagaku 1997, 65, 38-43. [CrossRef]

24. Wincewicz, K.C.; Cooper, J.S. Taxonomies of SOFC material and manufacturing alternatives. J. Power Sources 2005, 140, 280-296. [CrossRef]

25. Lee, H.W.; Park, M.; Hong, J.; Kim, H.; Yoon, K.J.; Son, J.W.; Lee, J.H.; Kim, B.K. Constrained sintering in fabrication of solid oxide fuel cells. Materials 2016, 9, 675. [CrossRef]

26. Singh, D.; Hernández-Pacheco, E.; Hutton, P.N.; Patel, N.; Mann, M.D. Carbon deposition in an SOFC fueled by tar-laden biomass gas: A thermodynamic analysis. J. Power Sources 2005, 142, 194-199. [CrossRef]

27. Grgicak, C.M.; Green, R.G.; Giorgi, J.B. SOFC anodes for direct oxidation of hydrogen and methane fuels containing H2S. J. Power Sources 2008, 179, 317-328. [CrossRef]

28. Schluckner, C.; Subotić, V.; Lawlor, V.; Hochenauer, C. Carbon deposition simulation in porous SOFC anodes: A detailed numerical analysis of major carbon precursors. J. Fuel Cell Sci. Technol. 2015, 12, 051007. [CrossRef]

29. Fernandes, M.D.; Bistritzki, V.; Domingues, R.Z.; Matencio, T.; Rapini, M.; Sinisterra, R.D. Solid oxide fuel cell technology paths: National innovation system contributions from Japan and the United States. Renew. Sustain. Energy Rev. 2020, 127, 109879. [CrossRef]

30. Lo Faro, M.; Trocino, S.; Zignani, S.C.; Aricò, A.S.; Maggio, G.; Italiano, C.; Fabiano, C.; Pino, L.; Vita, A. Study of a Solid Oxide Fuel Cell fed with n-dodecane reformate. Part I: Endurance test. Int. J. Hydrog. Energy 2016, 41, 5741-5747. [CrossRef] 
31. Lo Faro, M.; Trocino, S.; Zignani, S.C.; Italiano, C.; Vita, A.; Aricò, A.S. Study of a solid oxide fuel cell fed with n-dodecane reformate. Part II: Effect of the reformate composition. Int. J. Hydrog. Energy 2017, 42, 1751-1757. [CrossRef]

32. Zhan, Z.; Lin, Y.; Bamett, S. Anode catalyst layers for direct hydrocarbon and internal reforming SOFCs. Electrochem. Soc. 2005, 9, 1321-1330. [CrossRef]

33. Lo Faro, M.; Reis, R.M.; Saglietti, G.G.A.; Sato, A.G.; Ticianelli, E.A.; Zignani, S.C.; Aricò, A.S. Nickel-Copper/Gadolinium-doped Ceria (CGO) composite electrocatalyst as a protective layer for a Solid-Oxide Fuel Cell anode fed with ethanol. ChemElectroChem 2014, 1, 1395-1402. [CrossRef]

34. Lo Faro, M.; Reis, R.M.; Saglietti, G.G.A.; Zignani, S.C.; Trocino, S.; Frontera, P.; Antonucci, P.L.; Ticianelli, E.A.; Aricò, A.S. Investigation of Ni-based alloy/CGO electro-catalysts as protective layer for a solid oxide fuel cell anode fed with ethanol. J. Appl. Electrochem. 2015, 45, 647-656. [CrossRef]

35. Lo Faro, M.; Trocino, S.; Zignani, S.C.; Italiano, C.; Reis, R.M.; Ticianelli, E.A.; Aricò, A.S. Nickel-Iron/Gadolinium-doped Ceria (CGO) composite electrocatalyst as a protective layer for a Solid-Oxide Fuel Cell anode fed with biofuels. ChemCatChem 2016, 8, 648-655. [CrossRef]

36. Li, J.; Croiset, E.; Ricardez-Sandoval, L. Theoretical investigation of the methane cracking reaction pathways on Ni (1 11 1) surface. Chem. Phys. Lett. 2015, 639, 205-210. [CrossRef]

37. Lo Faro, M.; Frontera, P.; Antonucci, P.; Aricò, A.S. Ni-Cu based catalysts prepared by two different methods and their catalytic activity toward the ATR of methane. Chem. Eng. Res. Des. 2015, 93, 269-277. [CrossRef]

38. Laosiripojana, N.; Assabumrungrat, S. The effect of specific surface area on the activity of nano-scale ceria catalysts for methanol decomposition with and without steam at SOFC operating temperatures. Chem. Eng. Sci. 2006, 61, 2540-2549. [CrossRef]

39. Ioselevich, A.; Kornyshev, A.A.; Lehnert, W. Statistical geometry of reaction space in porous cermet anodes based on ion-conducting electrolytes patterns of degradation. Solid State Ion. 1999, 124, 221-237. [CrossRef]

40. Pecho, O.M.; Mai, A.; Münch, B.; Hocker, T.; Flatt, R.J.; Holzer, L. 3D microstructure effects in Ni-YSZ anodes: Influence of TPB lengths on the electrochemical performance. Materials 2015, 8, 7129-7144. [CrossRef]

41. Crosbie, G.M.; Murray, E.P.; Bauer, D.R.; Kim, H.; Park, S.; Vohs, J.M.; Gorte, R.J. Solid oxide fuel cells for direct oxidation of liquid hydrocarbon fuels in automotive auxiliary power units: Sulfur tolerance and operation on gasoline. SAE Trans. 2002, 111, 832-839. [CrossRef]

42. Mogensen, M.B. Direct conversion of hydrocarbons in Solid Oxide Fuel Cells: A review. ACS Division of Fuel Chemistry, Preprints. In Proceedings of the 224th ACS National Meeting, Boston, MA, USA, 18-22 August 2002; p. 498.

43. Sun, Y.F.; Zhou, X.W.; Zeng, Y.; Amirkhiz, B.S.; Wang, M.N.; Zhang, L.Z.; Hua, B.; Li, J.; Li, J.H.; Luo, J.L. An ingenious $\mathrm{Ni} / \mathrm{Ce}$ co-doped titanate based perovskite as a coking-tolerant anode material for direct hydrocarbon solid oxide fuel cells. J. Mater. Chem. A 2015, 3, 22830-22838. [CrossRef]

44. Moure, C.; Peña, O. Recent advances in perovskites: Processing and properties. Prog. Solid State Chem. 2015, 43, 123-148. [CrossRef]

45. Perry, N.H.; Ishihara, T. Roles of bulk and surface chemistry in the oxygen exchange kinetics and related properties of mixed conducting perovskite oxide electrodes. Materials 2016, 9, 858. [CrossRef] [PubMed]

46. Cascos, V.; Alonso, J.A.; Fernández-Díaz, M.T. Novel Mg-doped $\mathrm{SrMoO}_{3}$ Perovskites designed as anode materials for solid oxide fuel cells. Materials 2016, 9, 588. [CrossRef]

47. Bernuy-Lopez, C.; Høydalsvik, K.; Einarsrud, M.A.; Grande, T. Effect of A-site cation ordering on chemical stability, oxygen stoichiometry and electrical conductivity in layered $\mathrm{LaBaCo} 2 \mathrm{O} 5+\delta$ double perovskite. Materials 2016, 90, 154. [CrossRef]

48. Yao, Y.-F.Y. The oxidation of hydrocarbons and CO over metal oxides. IV. Perovskite-type oxides. J. Catal. 1975, 36, 266-275. [CrossRef]

49. Shimizu, T. Partial oxidation of hydrocarbons and oxygenated compounds on perovskite oxides. Catal. Rev. 1992, 34, 355-371. [CrossRef]

50. Niu, B.; Jin, F.; Yang, X.; Feng, T.; He, T. Resisting coking and sulfur poisoning of double perovskite $\mathrm{Sr}_{2} \mathrm{TiFe}_{0.5} \mathrm{Mo}_{0.5} \mathrm{O}_{6-\Delta}$ anode material for solid oxide fuel cells. Int. J. Hydrog. Energy 2018, 43, 3280-3290. [CrossRef]

51. Swartz, S.L. Sulfur tolerant fuel processing catalysts. ACS National Meeting Book of Abstracts. In Proceedings of the 230th ACS National Meeting, Washington, DC, USA, 28 August-1 September 2005; p. 1. 
52. Wang, S.; Jiang, Y.; Zhang, Y.; Li, W.; Yan, J.; Lu, Z. Electrochemical performance of mixed ionic-electronic conducting oxides as anodes for solid oxide fuel cell. Solid State Ion. 1999, 120, 75-84. [CrossRef]

53. Sammes, N.M.; Ratnaraj, R. High-temperature mechanical properties of $\mathrm{La}_{0.7} \mathrm{Sr}_{0.3} \mathrm{Cr}_{1-\mathrm{y}} \mathrm{Co}_{\mathrm{y}} \mathrm{O}_{3}$ in reducing environments. J. Mater. Sci. 1997, 32, 687-692. [CrossRef]

54. Xu, S.J.; Thomson, W.J. Stability of $\mathrm{La}_{0.6} \mathrm{Sr}_{0.4} \mathrm{Co}_{0.2} \mathrm{Fe}_{0.8} \mathrm{O}_{3-\delta}$ perovskite membranes in reducing and nonreducing environments. Ind. Eng. Chem. Res. 1998, 37, 1290-1299. [CrossRef]

55. Zhang, Y.; Sun, Y.F.; Luo, J.L. Ce/Ni decorated titanate based perovskite for solid oxide fuel cells. Ecs Trans. 2017, 75, 91-97. [CrossRef]

56. Lo Faro, M.; La Rosa, D.; Nicotera, I.; Antonucci, V.; Arico, A.S. Electrochemical investigation of a propane-fed solid oxide fuel cell based on a composite Ni-perovskite anode catalyst. Appl. Catal. B-Environ. 2009, 89, 49-57. [CrossRef]

57. Lo Faro, M.; Minutoli, M.; Monforte, G.; Antonucci, V.; Arico, A.S. Glycerol oxidation in solid oxide fuel cells based on a Ni-perovskite electrocatalyst. Biomass Bioenergy 2011, 35, 1075-1084. [CrossRef]

58. Lo Faro, M.; Stassi, A.; Antonucci, V.; Modafferi, V.; Frontera, P.; Antonucci, P.; Arico, A.S. Direct utilization of methanol in solid oxide fuel cells: An electrochemical and catalytic study. Int. J. Hydrog. Energy 2011, 36, 9977-9986. [CrossRef]

59. Lo Faro, M.; Antonucci, V.; Antonucci, P.L.; Aricò, A.S. Fuel flexibility: A key challenge for SOFC technology. Fuel 2012, 102, 554-559. [CrossRef]

60. Lo Faro, M.; Modafferi, V.; Frontera, P.; Antonucci, P.; Aricò, A.S. Catalytic behavior of Ni-modified perovskite and doped ceria composite catalyst for the conversion of odorized propane to syngas. Fuel Process. Technol. 2013, 113, 28-33. [CrossRef]

61. Lo Faro, M.; Arico, A.S. Electrochemical behaviour of an all-perovskite-based intermediate temperature solid oxide fuel cell. Int. J. Hydrog. Energy 2013, 38, 14773-14778. [CrossRef]

62. Lo Faro, M.; Reis, R.M.; Saglietti, G.G.A.; Oliveira, V.L.; Zignani, S.C.; Trocino, S.; Maisano, S.; Ticianelli, E.A.; Hodnik, N.; Ruiz-Zepeda, F.; et al. Solid oxide fuel cells fed with dry ethanol: The effect of a perovskite protective anodic layer containing dispersed Ni-alloy @ FeOx core-shell nanoparticles. Appl. Catal. B Environ. 2018, 220, 98-110. [CrossRef]

63. Lo Faro, M.; Oliveira, V.L.; Reis, R.M.; Saglietti, G.G.A.; Zignani, S.C.; Trocino, S.; Ticianelli, E.A.; Aricò, A.S. Solid Oxide Fuel Cell fed directly with dry glycerol. Energy Technol. 2019, 7, 45-47. [CrossRef]

64. Jardiel, T.; Caldes, M.T.; Moser, F.; Hamon, J.; Gauthier, G.; Joubert, O. New SOFC electrode materials: The Ni-substituted LSCM-based compounds $\left(\mathrm{La}_{0.75} \mathrm{Sr}_{0.25}\right)\left(\mathrm{Cr}_{0.5} \mathrm{Mn}_{0.5-\mathrm{x}} \mathrm{Ni}_{\mathrm{x}}\right) \mathrm{O}_{3-\delta}$ and $\left(\mathrm{La}_{0.75} \mathrm{Sr}_{0.25}\right)$ $\left(\mathrm{Cr}_{0.5-\mathrm{x}} \mathrm{Ni}_{\mathrm{x}} \mathrm{Mn}_{0.5}\right) \mathrm{O}_{3-\delta}$. Solid State Ion. 2010, 181, 894-901. [CrossRef]

65. Van Den Bossche, M.; McIntosh, S. Pulse reactor studies to assess the potential of $\mathrm{La}_{0.75} \mathrm{Sr}_{0.25} \mathrm{Cr}_{0.5} \mathrm{Mn}_{0.4} \mathrm{X}_{0.1} \mathrm{O}$ 3- $\delta(\mathrm{X}=\mathrm{Co}, \mathrm{Fe}, \mathrm{Mn}, \mathrm{Ni}, \mathrm{V})$ as direct hydrocarbon solid oxide fuel cell anodes. Chem. Mater. 2010, 22, 5856-5865. [CrossRef]

66. Lay, E.; Gauthier, G.; Dessemond, L. Preliminary studies of the new Ce-doped La/Sr chromo-manganite series as potential SOFC anode or SOEC cathode materials. Solid State Ion. 2011, 189, 91-99. [CrossRef]

67. Li, X.; Dai, L.; He, Z.; Meng, W.; Li, Y.; Wang, L. In situ exsolution of PdO nanoparticles from non-stoichiometric $\mathrm{LaFePd} 0.05 \mathrm{O} 3+\delta$ electrode for impedancemetric $\mathrm{NO}_{2}$ sensor. Sens. Actuators B Chem. 2019, 298, 126827. [CrossRef]

68. Hou, N.; Yao, T.; Li, P.; Yao, X.; Gan, T.; Fan, L.; Wang, J.; Zhi, X.; Zhao, Y.; Li, Y. A-site ordered double perovskite with in situ exsolved core-shell nanoparticles as anode for solid oxide fuel cells. ACS Appl. Mater. Interfaces 2019, 11, 6995-7005. [CrossRef]

69. Lo Faro, M.; La Rosa, D.; Nicotera, I.; Antonucci, V.; Aricò, A.S. Electrochemical behaviour of propane-fed solid oxide fuel cells based on low Ni content anode catalysts. Electrochim. Acta 2009, 54, 5280-5285. [CrossRef]

70. Vecino-Mantilla, S.; Quintero, E.; Fonseca, C.; Gauthier, G.H.; Gauthier-Maradei, P. Catalytic steam reforming of natural gas over a new Ni exsolved Ruddlesden-Popper manganite in SOFC anode conditions. ChemCatChem 2020, 12, 1453-1466. [CrossRef]

71. Kim, J.S.; Lee, J.Y.; Swinnea, J.S.; Steinfink, H.; Reiff, W.M.; Lightfoot, P.; Pei, S.; Jorgensen, J.D. Ruddlesden-Popper phases $\mathrm{An}+1 \mathrm{MnO} 3 \mathrm{n}+1$. Structures and properties. In Proceedings of the International Conference on the Chemistry of Electronic Ceramic Materials, Jackson, WY, USA, 17-22 August 1990; pp. 301-306. 
72. Lee, D.; Lee, H.N. Controlling oxygen mobility in ruddlesden-popper oxides. Materials 2017, $10,368$. [CrossRef]

73. Smith, R.D.L.; Prévot, M.S.; Fagan, R.D.; Zhang, Z.; Sedach, P.A.; Siu, M.K.J.; Trudel, S.; Berlinguette, C.P. Photochemical route for accessing amorphous metal oxide materials for water oxidation catalysis. Science 2013, 340, 60-63. [CrossRef]

74. Smith, R.D.L.; Prévot, M.S.; Fagan, R.D.; Trudel, S.; Berlinguette, C.P. Water oxidation catalysis: Electrocatalytic response to metal stoichiometry in amorphous metal oxide films containing Iron, Cobalt, and Nickel. J. Am. Chem. Soc. 2013, 135, 11580-11586. [CrossRef]

75. Tang, C.-W.; Wang, C.-B.; Chien, S.-H. Characterization of cobalt oxides studied by FT-IR, Raman, TPR and TG-MS. Thermochim. Acta 2008, 473, 68-73. [CrossRef]

76. Tiernan, M.J.; Barnes, P.A.; Parkes, G.M.B. Reduction of Iron oxide catalysts: The Investigation of kinetic parameters using rate perturbation and linear heating thermoanalytical techniques. J. Phys. Chem. B 2001, 105, 220-228. [CrossRef]

77. Li, C.; Chen, Y.W. Temperature-programmed-reduction studies of nickel oxide/alumina catalysts: Effects of the preparation method. Thermochim. Acta 1995, 256, 457-465. [CrossRef]

78. Marrero-Jerez, J.; Larrondo, S.; Rodríguez-Castellón, E.; Núñez, P. TPR, XRD and XPS characterisation of ceria-based materials synthesized by freeze-drying precursor method. Ceram. Int. 2014, 40, 6807-6814. [CrossRef]

79. Steele, B.C.H. Oxygen transport and exchange in oxide ceramics. J. Power Sources 1994, 49, 1-14. [CrossRef]

80. Liu, D.J.; Krumpelt, M. Activity and structure of perovskites as diesel-reforming catalysts for solid oxide fuel cell. Int. J. Appl. Ceram. Technol. 2005, 2, 301-307. [CrossRef]

81. Aguiar, P.; Lapeña-Rey, N.; Chadwick, D.; Kershenbaum, L. Improving catalyst structures and reactor configurations for autothermal reaction systems: Application to solid oxide fuel cells. Chem. Eng. Sci. 2001, 56, 651-658. [CrossRef]

82. Bastidas, D.M.; Irvine, J.T.S. LSCM based SOFC a suitable system for direct propane operation. In Proceedings of the 1st European Fuel Cell Technology and Applications Conference 2005-Book of Abstracts, Rome, Italy, 14-16 December 2005; p. 150.

83. Cheekatamarla, P.K.; Finnerty, C.M.; Cai, J. Internal reforming of hydrocarbon fuels in tubular solid oxide fuel cells. Int. J. Hydrog. Energy 2008, 33, 1853-1858. [CrossRef]

84. Douvartzides, S.L.; Coutelieris, F.A.; Tsiakaras, P.E. Effect of reforming on the overall efficiency of a solid oxide fuel-cell based power plant system fed by methane. Int. J. Exergy 2004, 1, 179-188. [CrossRef]

85. Lo Faro, M.; Vita, A.; Pino, L.; Aricò, A.S. Performance evaluation of a solid oxide fuel cell coupled to an external biogas tri-reforming process. Fuel Process. Technol. 2013, 115, 238-245. [CrossRef]

86. Manenti, F.; Pelosato, R.; Vallevi, P.; Leon-Garzon, A.R.; Dotelli, G.; Vita, A.; Faro, M.L.; Maggio, G.; Pino, L.; Arico, A.S. Biogas-fed solid oxide fuel cell (SOFC) coupled to tri-reforming process: Modelling and simulation. Int. J. Hydrog. Energy 2015, 40, 14640-14650. [CrossRef]

87. Al-Qattan, A.M.; Chmielewski, D.J. Distributed feed design for SOFCs with internal reforming. J. Electrochem. Soc. 2004, 151, A1891. [CrossRef]

88. Lim, L.T.; Chadwick, D.; Kershenbaum, L. Achieving autothermal operation in internally reformed solid oxide fuel cells: Simulation studies. Ind. Eng. Chem. Res. 2005, 44, 9609-9618. [CrossRef]

89. Georges, S.; Parrour, G.; Henault, M.; Fouletier, J. Gradual internal reforming of methane: A demonstration. Solid State Ion. 2006, 177, 2109-2112. [CrossRef]

90. De Lorenzo, G.; Corigliano, O.; Lo Faro, M.; Frontera, P.; Antonucci, P.; Zignani, S.C.; Trocino, S.; Mirandola, F.A.; Aricò, A.S.; Fragiacomo, P. Thermoelectric characterization of an intermediate temperature solid oxide fuel cell system directly fed by dry biogas. Energy Convers. Manag. 2016, 127, 90-102. [CrossRef]

91. Leah, R.; Bone, A.; Selcuk, A.; Corcoran, D.; Lankin, M.; Dehaney-Steven, Z.; Selby, M.; Whalen, P. Development of highly robust, volume-manufacturable metal-supported SOFCs for operation below $600{ }^{\circ} \mathrm{C}$. ECS Trans. 2011, 35, 351. [CrossRef]

92. Skinner, S.J.; Kilner, J.A. Oxygen ion conductors. Mater. Today 2003, 6, 30-37. [CrossRef]

93. Lo Faro, M.; Arico, A.S. Ceramic membranes for intermediate temperature solid oxide fuel cells (SOFCs): State of the art and perspectives. In Membranes for Clean and Renewable Power Applications; Gugliuzza, A., Basile, A., Eds.; Woodhead Publ Ltd.: Cambridge, UK, 2014; pp. 237-265. [CrossRef]

94. Coors, W.G. Protonic ceramic steam-permeable membranes. Solid State Ion. 2007, 178, 481-485. [CrossRef] 
95. Oishi, M.; Akoshima, S.; Yashiro, K.; Sato, K.; Mizusaki, J.; Kawada, T. Defect structure analysis of B-site doped perovskite-type proton conducting oxide $\mathrm{BaCeO}$. Part 2: The electrical conductivity and diffusion coefficient of $\mathrm{BaCe}_{0.9} \mathrm{Y}_{0.1} \mathrm{O}_{3-\delta}$. Solid State Ion. 2008, 179, 2240-2247. [CrossRef]

96. Ivanova, M.; Ricote, S.; Baumann, S.; Meulenberg, W.A.; Tietz, F.; Serra, J.M.; Richter, H. Ceramic materials for energy and environmental applications: Functionalizing of properties by tailored compositions. In Doping: Properties, Mechanisms and Applications; Nova Science Pub Inc.: New York, NY, USA, 2013; pp. 221-276.

97. Giannici, F.; Longo, A.; Deganello, F.; Balerna, A.; Arico, A.S.; Martorana, A. Local environment of Barium, Cerium and Yttrium in $\mathrm{BaCe}_{1-\mathrm{x}} \mathrm{Y}_{\mathrm{x}} \mathrm{O}_{3-\delta}$ ceramic protonic conductors. Solid State Ion. 2007, 178, 587-591. [CrossRef]

98. Shamsi, A.; Zahir, K. Oxidative-coupling of methane over Perovskite-type oxides and correlation of TMAX for oxygen desorption with C2 selectivity. Prepr. Symp. 1989, 34, 544. [CrossRef]

99. Mai, A.; Haanappel, V.A.C.; Uhlenbruck, S.; Tietz, F.; Stöver, D. Ferrite-based perovskites as cathode materials for anode-supported solid oxide fuel cells: Part I. Variation of composition. Solid State Ion. 2005, 176, 1341-1350. [CrossRef]

100. Liu, J.; Co, A.C.; Paulson, S.; Birss, V.I. Oxygen reduction at sol-gel derived $\mathrm{La}_{0.8} \mathrm{Sr}_{0.2} \mathrm{Co}_{0.8} \mathrm{Fe}_{0.2} \mathrm{O}_{3}$ cathodes. Solid State Ion. 2006, 177, 377-387. [CrossRef]

101. Dias, J.A.; Andrade, M.A.S.J.; Santos, H.L.S.; Morelli, M.R.; Mascaro, L.H. Lanthanum-Based Perovskites for Catalytic Oxygen Evolution Reaction. ChemElectroChem 2020. [CrossRef]

102. Zhu, L.; Wei, B.; Zhang, Y.; Lü, Z.; Wang, Z.; Huang, X.; Cao, Z.; Jiang, W.; Li, Y. Investigation on a novel composite solid oxide fuel cell anode with $\mathrm{La}_{0.6} \mathrm{Sr}_{0.4} \mathrm{Co}_{0.2} \mathrm{Fe}_{0.8} \mathrm{O}_{3-\delta}$ derived phases. Electrochim. Acta 2015, 160, 89-93. [CrossRef]

103. Benson, S.J.; Waller, D.; Kilner, J.A. Degradation of $\mathrm{La}_{0.6} \mathrm{Sr}_{0.4} \mathrm{Fe}_{0.8} \mathrm{Co}_{0.2} \mathrm{O}_{3-\delta}$ in carbon dioxide and water atmospheres. J. Electrochem. Soc. 1999, 146, 1305. [CrossRef]

104. Kim, H.; Lu, C.; Worrell, W.L.; Vohs, J.M.; Gorte, R.J. Cu-Ni cermet anodes for direct oxidation of methane in solid-oxide fuel cells. J. Electrochem. Soc. 2002, 149, A247. [CrossRef]

105. An, W.; Gatewood, D.; Dunlap, B.; Turner, C.H. Catalytic activity of bimetallic nickel alloys for solid-oxide fuel cell anode reactions from density-functional theory. J. Power Sources 2011, 196, 4724-4728. [CrossRef]

106. Nabae, Y.; Yamanaka, I.; Hatano, M.; Otsuka, K. Catalytic behavior of Pd-Ni/composite anode for direct oxidation of methane in SOFCs. J. Electrochem. Soc. 2006, 153, A140. [CrossRef]

107. Lo Faro, M.; Trocino, S.; Zignani, S.C.; Reis, R.M.; Monforte, G.; Ticianelli, E.A.; Aricò, A.S. Ni-based Alloys as Protective Layer for a Conventional Solid Oxide Fuel Cell Fed with Biofuels. ECS Trans 2015, 68, 2653-2658. [CrossRef]

(C) 2020 by the authors. Licensee MDPI, Basel, Switzerland. This article is an open access article distributed under the terms and conditions of the Creative Commons Attribution (CC BY) license (http://creativecommons.org/licenses/by/4.0/). 